https://helda.helsinki.fi

\title{
Urban parks provide ecosystem services by retaining metals and nutrients in soils
}

\section{Setälä, Heikki Martti}

2017

Setälä , H M , Francini , G , Allen , J , Jumpponen , A , Hui , N \& Kotze , D J 2017 , ' Urban parks provide ecosystem services by retaining metals and nutrients in soils ' , Environmental Pollution, vol. 231 , pp. 451-461 . https://doi.org/10.1016/j.envpol.2017.08.010

http://hdl.handle.net/10138/308202

https://doi.org/10.1016/j.envpol.2017.08.010

cc_by_nc_nd

acceptedVersion

Downloaded from Helda, University of Helsinki institutional repository.

This is an electronic reprint of the original article.

This reprint may differ from the original in pagination and typographic detail.

Please cite the original version. 


\title{
Urban parks provide ecosystem services by retaining metals and nutrients in soils
}

\author{
H. Setälä ${ }^{a^{*}}$, Francini ${ }^{\mathrm{a}}$, J.A. Allen ${ }^{\mathrm{a}}$, A. Jumpponen ${ }^{\mathrm{b}}$, H. Nan ${ }^{\mathrm{a}}$, G. D.J. Kotze ${ }^{\mathrm{a}}$
}

\section{Abstract (max 300 words)}

Urban greenspace can provide many of the same ecosystem services as more natural ecosystems. For instance, vegetation modifies soil properties, such as $\mathrm{pH}$ and soil organic matter content, yet little is known about its effect on, e.g. metals. We investigated whether the accumulation and mobility of heavy metals, nutrients and carbon is affected by plant functional types (evergreen or deciduous trees, lawns) in urban parks of varying ages in southern Finland. Plant types modified soil physical-chemical parameters differently, which was associated with diverging accumulation and mobility of many of the metals and other elements in parks soils. However, the influence of plant functional type was dependent on park age: for example, lawns in parks of ca. 50 y old had the highest contents of $\mathrm{Cr}, \mathrm{Cu}, \mathrm{Fe}, \mathrm{Mn}, \mathrm{Ni}$, and $\mathrm{Zn}$, and in these, and older parks ( $<100$ y old), contents of most metals were lowest under evergreen trees. The mobility of metals and other elements was influenced by the amount of water leached through the soils. Evergreen trees in young parks and lawns in intermediately-aged parks were most permeable to water, and as such had high loads of $\mathrm{Ca}, \mathrm{Cr}, \mathrm{Cu}, \mathrm{Fe}, \mathrm{Ni}$, tot-P and tot-N. The load/concentration of elements in the leachates was not clearly reflected by their content/concentration in the soil, thus suggesting the storage capacity of these elements in urban park soils.

Keywords: Ecosystem service, Lysimeter, Plant functional type, Traffic pollution,

Bullet points (3-5; max 85 characters, submitted as a separate file: "Highlights")

- Soils are modified by plant type and park age

- Vegetation and park age affect metal, nutrient and carbon content in the soil

- Mobility of metals and other elements depends on plant type and park age 
- Park soils can provide a vital metal storage ecosystem service

\section{Introduction}

Heavy metals occur naturally in soils and are predominantly derived from soil parent material (Longhurst et. al., 2004). Urban milieus, especially their soils, are further enriched with heavy metals because of various anthropogenic activities, such as the combustion of fossil fuels (Wong et al., 2006; Elless et al., 2007, Yesilonis et al., 2008). Sites close to main traffic routes are typically enriched with heavy metals originating from tire wear particles and weathered street surfaces (Chen et al., 2005, Salonen and Korkka-Niemi, 2007; Amato et al., 2009). As metals are often rather immobile once deposited on the soil surface, accumulation occurs in soils (Thornton, 1991, Yong et al., 1992) and can alos be detectable in plant tissues (Jumpponen and Jones, 2010). Heavy metals can come into contact with humans as suspended dust or they may be ingested by children and adults in playgrounds and urban parks (Ljung et al., 2006). As a result, heavy metals and their accumulation in urban environments can adversely impact human health (Thornton, 1991; Rabito et al., 2003). Additionally, because of the high proportion of sealed surfaces, urbanderived metals can flush away via urban runoff (Valtanen et al., 2014, 2015), causing the contamination of adjacent water bodies (Davis et al. 2001).

Urban greenspaces provision important ecosystem services (ESS) (Wall et al., 2015). Growing evidence suggests that, besides urban green infrastructure (i.e., plants), urban soils can provide many similar ESS as non-urban soils do (Pouyat et al., 2010; Setälä et al., 2014). For example, urban soils store considerable amounts of carbon and nitrogen (Franzlubbers, 2002; Pouyat et al., 2010; Edmonson et al. 2014a; Setälä et al. 2016), purify urban runoff water (Valtanen et al., 2015; Taka et al., 2017) and detoxify harmful substances (Lehman and Stahr, 2007). As many of these beneficial ESS relate to the volume and quality of soil organic matter (SOM) (Lal, 2004; Allison, 2006), and because the quality 
and quantity of SOM is controlled by the type and quantity of local vegetation (Bardgett and Wardle, 2010), understanding the interactions between urban vegetation and their soils is pivotal in mitigating the various adverse effects of anthropogenic contamination (Acosta et al., 2014). However, because of recurring and continuous structural disturbance and contamination with various pollutants, the ability of urban soils to provide ESS may be limited Even though some plants and soil organisms can mitigate the adverse effects of and even detoxify organic toxicants, such as polyaromatic hydrocarbons or PAHs (Reid et al., 2000; Couling et al., 2010), soil biota may be less likely to directly and efficiently reduce the harmful effects of non-biodegradable elements, such as metals.- Furthermore, although urban vegetation may directly influence pollution loads by protecting against aerial deposition onto the soil (Trammel et al., 2011; Curran-Cournane et al., 2015), little, if anything, is known about its effects on metal accumulation within urban habitats.

Besides direct effects by some hyperaccumulator plants (see McGrath and Chao, 2003) and fungi (see Colpaert et al., 2011), the plant-soil system can also indirectly mitigate the adverse effects of heavy metal contamination. Growing evidence suggests that vegetation strongly controls soil properties and biogeochemical processes in natural and urbanised habitats (Wardle, 2002; Bardgett and Wardle, 2010; Buol et al., 2011; Edmonson et al., 2014b; Ossola et al., 2015). For example, soil pH, \%OM and pools of $\mathrm{C}$ and $\mathrm{N}$ can be influenced not only by the quantity (Pouyat et al., 2009; Livesley et al., 2016) but also by the quality of urban vegetation (Edmonson et al. 2014b; Setälä et al. 2016). Importantly, because SOM content can affect trace metal concentrations in urban soils (Brown et al., 2003; Lair et al., 2007; Pouyat et al., 2010; Acosta et al., 2014), it is possible that, by accumulating organic matter in the rhizosphere soils, plants can efficiently bind metals and thus control their mobility in the system.

Our previous studies conducted in urban parks in southern Finland, indicated that both plant functional type and park age affect soil $\mathrm{pH}$, soil OM content, concentrations of soil C and N (Setälä et al., 2016) and soil microbial community composition (Nan et al., 2017). However, the influence of plant functional type and park age on (i) metal concentrations and (ii) their mobility in these urban greenspaces remain unknown. Only little information is available about the role of vegetation in the mobility of heavy metals in urban soils (Acosta et al., 2014), and our knowledge on the effects of plant functional types on heavy metal dynamics is virtually nonexistent. Similarly to vegetation, park age can also affect the density and composition of heavy metals in urban soils. For example, Chen et al. (2005) and Guo et al. (2012) reported that old parks have higher concentrations of $\mathrm{Pb}$ and $\mathrm{Cu}$ compared to young parks in China, while Ljung et al. (2006) found an increasing trend of an array of 
trace metals with the age of urban greenspaces in Sweden. These findings likely relate to the extended period of time old parks have been exposed to metal contamination driven by anthropogenic activities. It is also possible that the increasing density of OM in park soils with park age (Golubiewski, 2006; Raciti et al., 2011, Setälä et al., 2016) increases the capacity of old soils to immobilize C and nutrients (Brown et al., 2003; Lair et al., 2007; Pouyat et al., 2010) in addition to heavy metals (see Acosta et al., 2014).

We aimed to investigate whether the potential of plant functional types (evergreen or deciduous trees and lawns) to modify soil OM content, texture and bulk density is reflected in the accumulation and mobilisation/immobilisation of heavy metals, $\mathrm{N}, \mathrm{P}$ and dissolved organic carbon (DOC) in urban parks of varying ages. These components were studied in the soil as well as soil leachates collected with lysimeters.- We hypothesized that (1) divergent plant functional types, each producing differently decomposable litter (Ponge, 2003; Bardgett and Wardle, 2010) differ in their ability to (i) store and retain water, nutrients and metals in their rhizospheres and thus (ii) affect the mobility of these elements in park soils. This is because plants producing, e.g., recalcitrant (evergreen trees) or labile (e.g. grasses and deciduous trees) litter can modify the physical-chemical-biological characteristics of urban soils differently (Edmonson et al., 2014a,b; Liveslay et al., 2016; Setälä et al., 2016; Nan et al., 2017). Furthermore, we predicted that (2) soils in old parks are, due to their long history of plant-soil interactions, more modified by plants and thus differ in ability to retain water and elements from young parks. We also hypothesized that (3) young parks accumulate less and leach relatively more heavy metals than older parks. This is because of (i) the much shorter time the former parks have been exposed to, e.g. trafficderived metal (except lead) deposition, and (ii) the lower \%OM in young vs. old park soils (see Setälä et al., 2016). Finally, we predicted that heavy metals are more evenly distributed among soil layers in older parks than in young parks. This is because of the longer contamination history and potential substrate homogenisation over time in these older parks.

\section{Materials and methods}

\subsection{Study area}


We selected 41 urban parks in the cities of Helsinki $\left(60^{\circ} 10^{\prime} 15^{\prime \prime} \mathrm{N}, 024^{\circ} 56^{\prime} 15^{\prime \prime} \mathrm{E}\right.$, population size of ca. 1.4 million people) and Lahti $\left(60^{\circ} 59^{\prime} 00^{\prime \prime} \mathrm{N}\right.$, $25^{\circ} 39^{\prime} 20^{\prime \prime}$ E, population size of 102000 ), and 5 additional control forests (in the proximity of Lahti) in southern Finland. Climatic and edaphic information of Helsinki and Lahti can be found in Setälä et al. (2016). The urban parks, belonging to the Finnish LTSER-site network (Forsius et al., 2013), represented different ages: more than 100 years old (the oldest parks were established over two centuries ago), $50 \pm 10$ years old and 5 - 15 years old, referred to as old, intermediate and young parks, respectively. Park managers assisted us in the selection of parks and study sites therein, and provided the necessary background information on park construction, park management practices and the planting of trees and other vegetation during and after park construction. We also considered three plant functional groups in these parks: individual evergreen (Picea sp. 43.3\%; Abies sp. 20\%; Pseudotsuga menziesii 13.3\%; Pinus sylvestris 13.3\%; Larix sp. 10\%) or deciduous (Tilia x vulgaris 93\%; Acer platanoides 7\%) trees and lawn (mostly Poa and Festuca species with scattered herbs such as Trifolium pratense and Plantago major).. Distance between the two tree types was always greater than the height of the tallest tree. The age of plants within each park age class corresponded with the age of the park, except for the young parks where trees are commonly planted as ca. 10 year old saplings at the time of park construction. The evergreen and deciduous trees also had lawn cover within the sampled area. The ideal field design would have included 15 parks per city, represented by five old, five intermediate and five young parks, with all three plant functional groups present. However, since some parks did not include all three plant functional groups, we also selected parks with one or two plant functional groups present. This resulted in a total of 41 urban parks and 91 urban sampling locations with at least 10 replicates per park age and plant functional group (for more details, see Hui et al. 2017). Park sizes varied considerably, ranging from ca. 0.1 ha to several hectares, but with no systematic grouping of size with park age and plant functional group.

The main source of heavy metals in the larger metropolitan area is traffic (Aarnio et al. 2001; K. Kähäri, Lahti City Environmental Services, personal information). Given the variation in park size, the proximity of soil sampling plots (see below) to adjacent roads varied between the parks. Furthermore, traffic intensity (not quantified in the current study) likely differs between roads close to the parks. However, the divergent plant functional types within a park are situated at equal distance from the main road(s) and other potential polluting sources. In the city of Lahti, parks belonging to the three age-classes were randomly distributed within the city, whereas in Helsinki the oldest parks tended to be closer to the urban core than the intermediate and young parks. In addition to atmospheric deposition, urban park soils are also disturbed by 
trampling, mowing and raking. The parks were frequently mown but were not irrigated or commonly fertilized. Until the early 1990s, some of the older parks in the city of Lahti were occasionally fertilized - commonly with saltpeter $(\mathrm{N}, \mathrm{P}, \mathrm{K}, \mathrm{S})$ with negligible amounts of heavy metals, while some of the park lawns in Helsinki have received and still receive light refurbishment fertilization.

To compare urban parks to habitats with lesser anthropogenic influence, we chose 5 natural to semi-natural mixed forests with Norway spruce (Picea abies L.) and forest linden (Tilia cordata L.) trees as control sites near to the city of Lahti. These forests represented "old forests" (> 80 year old), but had no turf-grass. Consequently, the control forests were only compared to evergreen and deciduous trees (lawns excluded) of the old parks in Lahti.

\subsection{Soil sampling and edaphic conditions}

To investigate soil heavy metals, tot-P, bulk density (BD) and soil water content, soils were sampled in October 2014 (parks) and May 2015 (control forests) at the outer edge of the canopy projection (evergreen and deciduous trees) so that distance to the nearest tree trunk ranged from $1 \mathrm{~m}$ (young parks with small trees) to several meters (old parks with large trees). Distance from the sampling plots and the excavated lysimeter pits (see below) to the edge of tree planting holes, which were still recognizable in some young parks, was always $>30 \mathrm{~cm}$. The lawn soils (in parks only) were sampled at least at a distance equal to the height of the nearest tree to minimize the effect of adjacent trees and their roots. At each sampling point, samples were collected using a steel push corer $(2.54 \mathrm{~cm}$ diameter $)$ to a depth of $50 \mathrm{~cm}$. The soil samples were divided vertically into $0-10,11-20$ and $21-50 \mathrm{~cm}$ sections and transported in a cooler to the laboratory for further analyses. A total of 270 park soil samples ( 2 cities, $\mathrm{x} 3$ park age classes x 3 vegetation types x 3 soil depths x 5 replicates) and 20 control forest soil samples ( 1 city x 1 age x 2 tree types $x 2$ soil depths) were analysed. Only the uppermost $0-10 \mathrm{~cm}$ and $11-20 \mathrm{~cm}$ soil layers were sampled in the rocky control forest soils that made deeper cores impossible. Before analyses, the samples were sieved through a $2 \mathrm{~mm}$ mesh to remove plant litter, rocks, large particles and roots. Soil water content was analysed by drying the soils at $105{ }^{\circ} \mathrm{C}$ for $24 \mathrm{~h}$. Samples for soil bulk density (BD) analysis were collected in the summer of 2016 from each site using a bulk density sampling kit (Part \# 400.80, AMS, Inc., USA) according to the manufacturer's instructions. A single set of cores was collected from the approximate midpoint of each of the three depth intervals and placed into labeled plastic 
bags for storage prior to analysis. Dry weight BD was determined using standard methods for soil bulk density analysis. Percent sand, silt and clay was determined using sieved soil from each depth interval using the Bouyoucos hydrometer method with sodium hexametaphosphate (Lot\# BCBP9072V, Sigma-Aldrich Chemie GmbH, Steinheim, Germany) as the dispersing agent.

Samples for total metal and tot-P analyses were taken from the sieved soil material and submitted for analysis to the University of Helsinki's Alma Laboratory in Lahti. The sample (typically $100 \mathrm{mg}$ fresh soil) was digested with $10 \mathrm{ml}$ of concentrated nitric acid in a MARS 6 microwave digestion unit (CEM Corporation P.O. Box 200 Matthews, NC 28106 United States), diluted to 2\% nitric acid concentration (v/v), and analysed with indium as the internal standard. For the analyses of soil \%OM, soil tot-N, tot-C and soil pH, see Setälä et al. (2016).

\subsection{Soil lysimeters}

To collect water leachates from the park soils, zero-tension lysimeters (pan lysimeters) were inserted into the soil in late May 2014. These "passive lysimeters" were constructed by cutting $30 \mathrm{~cm}$ long sections of $10 \mathrm{~cm}$ diameter PVC pipes lengthwise to form two open troughs. The lysimeters were installed at a slight upward angle into the sidewall of an excavated $60 \mathrm{~cm}$ deep pit, approximately $15 \mathrm{~cm}$ below the surface. During active monitoring periods (see below), $1 \mathrm{~L}$ plastic sampling vials were placed in containers within the pits. The pits were covered at all times using a container lid and the turf grass plug that was removed during excavation. Because of the rocky soils in the control forests, no lysimeters could be installed there.

Unusually dry weather during the summer and fall of 2014 and 2015 resulted in poor sample collection success. The lysimeter vials were checked for leachates in September 2014, but because of the minimal water yields, the vials were removed without further analyses and replaced with new ones in late September 2014. After 1 mo incubation, the vials were collected and transported to the laboratory (first sampling event). The soil water was lysimeterically sampled again between mid-May and mid-June 2015 (second sampling event). To counter the dry conditions during the summer and fall of 2015, the area above the lysimeters was manually watered twice during early October and late November of 2015. During each round, $5 \mathrm{~L}$ of tap water from the city of Lahti, Finland was sprayed onto the soil overlying the lysimeters over a period of 15 min, using $10 \mathrm{~L}$ capacity pressurized sprayers $\left(1^{\text {st }}\right.$ irrigation event) or a $8 \mathrm{~L}$ watering can $\left(2^{\text {nd }}\right.$ irrigation $)$. A period of active monitoring was begun 
immediately after the second irrigation event and leachate samples from the soils "primed" with irrigation water were collected November/December 2015 (third sampling event). In all, the first two sets of water samples were derived from precipitation whereas the last one was derived from irrigation and some rain water. After each sampling event, lysimeter vials were placed in coolers, transported to the laboratory and frozen $\left(-18^{\circ} \mathrm{C}\right)$ before analyses. Prior to analyses, the sampled water was melted for the analysis of dissolved metals, nutrients and carbon. For the analysis of water soluble metals, tot-N, $\mathrm{NO}_{3}-\mathrm{N}$, tot-P and DOC, the leachates were filtered through a $0.45 \mu \mathrm{m}$ syringe filter (PES). For soluble metals and tot-P, $5 \mathrm{ml}$ of the filtered sample was transferred into a test tube. Concentrated $\mathrm{HNO}_{3}(50 \mu 1$, Merc Suprapur) and $50 \mu 1$ of 1 $\mathrm{mg}^{-1}$ indium solution (internal standard) were added. Metal concentrations were determined using a Perkin Elmer Elan 6000 ICP-MS according to SFS-EN ISO 17294-2 (2005). Concentrations of DOC in the leachates were measured using the Apollo 9000hs TOC Analyser applying the SFS-EN 1484 method, and those of tot-N using the High Performance Liquid Chromatography (HPLC) instrument with 0.04 M sodium chloride $(\mathrm{NaCl})$ as an eluent according to ISO 29441:2010.

To quantify (in mass units per surface area) the ability of park soils to retain metals and other elements that can potentially leach down in the soil profile via rain water, we present the element data in soils as pools $\left(\mathrm{g} \mathrm{m}^{-2}\right)$ and in water leachates as loads (mg $\left.\mathrm{m}^{-2}\right)$. However, to make our results comparable to studies that commonly report such data as concentrations ( $\mathrm{mg} \mathrm{kg}^{-1}$ dry soil), we also present these concentrations in the Supplementary Material, Table S1. Due to difficulties with placing zero-tension lysimeters in the control forests with stony soils, no lysimeter data were collected for those sites.

\subsection{Statistical analyses}

Generalized linear mixed effect models (GLMM) were employed to analyse our data, using the lmer function of the lme4 library in R (R Core Team, 2016). Metal pools and other elements were transformed to normality where necessary. The soil elements (\% soil moisture, bulk density, \% sand, \% silt, \% clay, $\mathrm{P}, \mathrm{Fe}, \mathrm{Cr}, \mathrm{Mn}, \mathrm{Ni}, \mathrm{Zn}, \mathrm{Cu}, \mathrm{Cd}, \mathrm{Pb}$ ) were analysed as follows. Individual models included plant functional type as a factor (evergreen trees, deciduous trees, lawn), park age as a factor (young, intermediate, old), sampling depth as a factor (0-10 cm, 11-20 cm, $21-50 \mathrm{~cm})$, and their two- and three-way interactions. Park, nested in city was included as a random term to incorporate potential variation 
associated with multiple plant functional types per park and the sampling of two cities. Model selection proceeded by removing predictor variable interactions if their p-values were greater than 0.1 , starting with the three-way interaction, and then the two-way interactions. Plant functional type, park age and sampling depth were not removed (main effects), even if their p-values were greater than 0.1 .

Soils of the control (natural) forests in Lahti were compared to soils under evergreen and deciduous trees in old parks in Lahti. The linear models included vegetation type (a four level factor including natural evergreen forest, park evergreen trees, natural deciduous forest and park deciduous trees), sample depth (a two-level factor including 0-10 cm and 11-20 cm), and their interaction. The interaction term was removed if not significant ( $\mathrm{p}$-value $>0.1)$.

Element pools in the lysimeter leachate (water volume, $\mathrm{P}$, the metals above, including $\mathrm{Al}, \mathrm{Co}, \mathrm{V}, \mathrm{As}, \mathrm{Se}, \mathrm{Be}$, tot-N, NO${ }_{3} \mathrm{~N}, \mathrm{DOC}$ ) were analysed as follows. Due to the large number of missing data points (no leachate in the sampling bottles), a two-step approach, analogous to hurdle models, was used. First, we analysed the probability of occurrence of the elements in the leachate, given that there was leachate in the sampling bottle. This is a presence-absence model, with the response following a binomial distribution. Second, if there was leachate in the sampling bottle, we used only these samples to calculate the pools in a lognormal model. Both models, per element, followed the same structure, including the following predictor variables; plant functional type and park age as factors and their interaction, \% clay in the soil, soil bulk density, \% soil moisture, soil $\mathrm{pH}$, soil $\mathrm{OM}$, and if available, the concentration of that particular element in the soil. The random term included event (three sampling events per park) nested in park, nested in city. Model selection proceeded by removing insignificant terms ( $p>0.1$ ), except for the plant functional type and park age terms, which were retained in the final models irrespective of their significance.

\section{Results}

\subsection{Soil bulk density}


Bulk density was consistently higher under lawns irrespective of park age, and increased with park age, except under evergreen trees, where it decreased with park age. BD increased significantly deeper into the soil in young and intermediate parks, whereas the soils in old parks were equally dense irrespective of soil depth (Fig. 1, Table 1). Compared to control forests (mean \pm SE: evergreen trees $0.83 \pm 0.06$; deciduous trees $=0.83 \pm 0.06)$, BD in old parks in Lahti was significantly higher under both evergreen $(1.11 \pm 0.06)$ and deciduous trees $(1.17 \pm 0.06)$, but did not differ among soil depths (Supplementary Material, Fig. S1, Table S2).

\subsection{Soil texture}

At the park level (park plant functional types and soil depths pooled), soils were mainly loamy sand and sandy (clay) loam soils (Supplementary Material, Fig. S2). More specifically, samples were mainly composed of sand (ca. 68\%), followed by silt (ca. 18\%) and clay (ca. 13\%). Plant functional type had no clear effect on soil texture, except that soils under young deciduous trees had a higher percentage of sand, and consequently lower percentages of silt and clay. Also, \% sand was lowest and \% clay highest in lawns (across age categories). Soil texture differed little between plant functional types in intermediate and old parks, and no consistent pattern existed between soil depths (Supplementary Material, Table S2).

\subsection{Soil water content}

Soil moisture was higher under lawns than under evergreen and broadleaf trees. Young parks tended to be drier than intermediate and old parks, which indicates compaction and poor infiltration in the older parks, and top soils were significantly more moist than deeper soil layers (Fig. 1, Table 1). Soils in the control forests in Lahti were significantly more moist (evergreen trees $31.38 \% \pm 1.46$; deciduous trees $32.64 \% \pm$ 1.46) than soils under old park trees (evergreen trees $22.57 \% \pm 1.43$; deciduous trees $23.26 \% \pm 1.43$ ), and the top soils $(0-10 \mathrm{~cm})$ were more moist than the deeper soil layers (11-20 cm (Supplementary Fig. S1, Table S2). 
3.4. Heavy metals and tot-P in the soil

Plant functional type, park age and soil depth had varying effects on the concentrations (see Supplementary Material, Table S1) and pools of heavy metals in the park soil. Some of these elements were influenced by plant type but this effect often depended on park age. Soils under lawn had generally higher pools of metals, often in young and particularly in intermediate parks (e.g, Cr, Mn, Ni, Fe, Zn, Cu). Pools of all metals were low under deciduous trees in young parks, and under evergreen trees in the older parks. Otherwise, plant functional type had no consistent effect on these elements (Fig. 1, Table 1). Concentrations of Cd were below the detection limit $\left(2.5 \mathrm{mg} \mathrm{kg}^{-1}\right)$, which translates to Cd pools below $0.25 \mathrm{~g} \mathrm{~m}^{-2}$ in the parks.

Pools of $\mathrm{Cr}, \mathrm{Cu}, \mathrm{Mn}, \mathrm{Zn}$, and particularly $\mathrm{Pb}$ were lowest in young parks, while the differences in metal pools between the two older parks were often small (Fig. 1, Table 1). Apart from $\mathrm{Pb}$, pools of trace metals were lowest under evergreen trees in intermediate and old parks (Fig. 1). Lead ( $\mathrm{Pb}$ ) increased significantly in load as parks aged. In terms of depth: $\mathrm{Zn}, \mathrm{Cu}$ and $\mathrm{Pb}$ pools varied little between sampling depths per plant functional type and park age. The other metals varied more with sampling depth, often with inconsistent patterns across plant type and age. In old parks (irrespective of plant functional type), pools of $\mathrm{Fe}, \mathrm{Cr}, \mathrm{Cu}$, and to some degree Ni were always lowest in the deepest soil layer.

Plant functional type affected tot-P pools in the park soils, but this effect depended on park age; tot-P was lowest under deciduous trees in young and intermediate parks but highest in old parks. Pools of tot-P declined consistently with soil depth irrespective of plant type and park age (Fig. 1, Table 1).

In general, metals in the soils of old urban parks (evergreen and broadleaf park soils respectively; Fe 2510 and 2945, Cr 4.01 and 5.15, Ni 2.04 and 2.44, $\mathrm{Zn} 14.67$ and 17.50, $\mathrm{Cu} 3.36$ and 2.83, $\mathrm{Pb} 2.68$ and $2.80 \mathrm{~g} \mathrm{~m}^{-2}$ ) were significantly higher than in the control forests (evergreen and broadleaf control forest soils respectively; Fe 1217 and 1252, $\mathrm{Cr} 1.85$ and 1.89, Ni 1.05 and 1.00, $\mathrm{Zn} 9.57$ and 10.21, Cu 0.95 and 0.91, Pb 1.57 and $1.32 \mathrm{~g} \mathrm{~m}^{-2}$ ). Pools and concentrations of tot-P were more than twice as high in the old parks (evergreen 168.69 , deciduous $139.64 \mathrm{~g} \mathrm{~m}^{-2}$ ) than in the control forest soils (evergreen 65.88, deciduous $64.28 \mathrm{~g} \mathrm{~m}^{-2}$ ). None of the elemental pools differed with soil depth (see Supplementary Material Fig S1, Table S2). 
Finally, we correlated the percentage of organic matter $(\% \mathrm{OM})$ and $\mathrm{pH}$ in the soil with elemental concentrations, since $\% \mathrm{OM}$ is known as a strong sorbent of heavy metals and other elements in urban soils. Correlations were generally weak, and \%OM was most strongly correlated with tot-P $(\mathrm{r}=0.29, \mathrm{p}<0.001), \mathrm{Pb}(\mathrm{r}=0.25, \mathrm{p}<0.001), \mathrm{Cu}(\mathrm{r}=0.25, \mathrm{p}<0.001)$ and $\mathrm{Zn}(\mathrm{r}=0.17, \mathrm{p}=0.006)$. Correlations between metals and $\mathrm{pH}$ were generally negative $(\mathrm{Cr} r=-0.28, \mathrm{p}<0.001 ; \mathrm{Mn} \mathrm{r}=-0.27, \mathrm{p}<0.001 ; \mathrm{Fe} \mathrm{r}=-0.25, \mathrm{p}<0.001 ; \mathrm{Ni} \mathrm{r}=-0.24, \mathrm{p}<0.001 ; \mathrm{Zn} \mathrm{r}=-0.14, \mathrm{p}=$ 0.03). Concentrations of tot-P did not correlate with soil pH (see Supplementary Material Fig S2 \& Table S3).

\subsection{Metals, nutrients and carbon in water leachates (loads)}

For purposes of brevity, we do not present results of the binomial models here (except for water volume in the sample vials). In these models, the probability of occurrence of the element in the leachate is tested, given that the sampling bottles had leachate in them. These results are presented in the Supplementary Material Table S4.

The amount of water leaching through the soils was low, likely because of the exceptionally dry summer and autumn of 2014 and 2015 (precipitation in Lahti and Helsinki during September - December $<150 \mathrm{ml}$ in both years; Lahti: data from the University of Helsinki, Lahti measurement Station; Helsinki: http://suja.kapsi.fi/fmi-tilastot.php?kuumoodi=true\&kuukausi=09\&vuosi=2015). The probability that water leachate occurred in the sample vials varied between ca. 0.3 (deciduous trees in young parks) and 0.6 (lawn in young parks) with no consistent difference between plant functional type or park age (Supplementary Material Fig. 2). The amount of water leachate detected in the lysimeter vials did not differ between plant types and park ages. However, variation in the amount of water leachates between the three plant types was larger in young and intermediate parks compared to the old parks (Fig. 2, Table 2). Lawns in intermediate parks and evergreen trees in young parks were particularly permeable (leaky) in terms of water volume. In the young parks, deciduous trees were least permeable (see Fig. 2).

Leaching of the water soluble fraction of heavy metals $(\mathrm{Cd}, \mathrm{Cr}, \mathrm{Cu} \mathrm{Mn}, \mathrm{Ni}, \mathrm{Pb}, \mathrm{Zn})$ was neither consistently affected by plant functional type nor park age (Fig. 2, Table 2). However, leaching of most of these heavy metals was high in young parks under evergreen trees, whereas their loads were particularly low under deciduous trees in young parks. Similarly, while the loads of the two non-metals As and Se and the metals $\mathrm{Co}$, Va and Be were not clearly affected by plant type or park age, there was a clear plant functional type $\times$ park age interaction: loads were 
generally large under evergreen trees in young parks and under deciduous trees in intermediate parks, while the loads were always low, irrespective of plant type, in old parks. Loads of most metals and non-metals were clearly low under lawn in the old parks.

Loads of tot-P (water soluble fraction) were affected by plant functional type but this effect was park age dependent: in young park evergreen trees associated with the highest loads of tot-P, while in intermediate parks highest loads were detected under lawn. Leaching of tot-N followed roughly a pattern similar to tot-P, whereas that of $\mathrm{NO}_{3}-\mathrm{N}$ showed higher leaching under intermediate lawns and old evergreen trees. In young parks, the proportion of $\mathrm{NO}_{3}-\mathrm{N}$ of the total $\mathrm{N}$ was particularly low under evergreen trees, while in old parks virtually all of the $\mathrm{N}$ leached under evergreen trees was in the form of $\mathrm{NO}_{3}-\mathrm{N}$. As for DOC, plant type had little influence on its leaching, except for intermediate parks where the loads were more than 5 times larger under lawn than under the two tree types (Fig 2, Table 2). Note that large variation existed in certain sample localities for $\mathrm{NO}_{3} \mathrm{~N}$, tot-N and DOC.

Six soil variables (\%soil moisture, \%OM, \%clay, soil $\mathrm{pH}$, bulk density and the concentration of a given element in the soil) were included in the GLMM models to evaluate their effect on the occurrence and load of elements in the leachate. Soil moisture - retained in 12 of the 19 lognormal models - was positively related with the volume of leached water $(p=0.018)$, loads of most metals $(p<0.04-0.096)$ and tot-P $(p=$

0.06). Loads of tot- $\mathrm{N}$ and $\mathrm{NO}_{3}-\mathrm{N}$ responded negatively to soil moisture. Soil organic matter $(\% \mathrm{OM})-$ retained in 8 models - was negatively related to the volume of leached water $(\mathrm{p}=0.029)$ and the loads of $\mathrm{Cu}, \mathrm{Fe}, \mathrm{Mn}, \mathrm{Pb}, \mathrm{Va}(\mathrm{p}=0.029-0.10)$. Of the nutrients, tot-N was positively $(\mathrm{p}=0.024)$ while tot-P negatively $(\mathrm{p}=0.008)$ related to \%OM in the soil. Soil $\mathrm{pH}$ - retained in 4 models - had a negative impact on the leaching of $\mathrm{Mg}, \mathrm{Zn}, \mathrm{Pb}$ and tot- $\mathrm{N}(\mathrm{p}<0.01-0.042)$. The percentage of clay, bulk density and, surprisingly, the concentrations of metals and nutrients in the soil had minor effects on the loads of elements in the leachate (Table 2).

\section{Discussion}

Overall, concentrations (see Supplementary Material, Table S1) of heavy metals in urban park soils were comparable to those in other cities in southern Finland (Kohonen and Salminen, 1993; Salminen, 1995; Salla, 1999; Salonen and Korkka-Niemi, 2007) and, from a global 
perspective, similar to those reported for cities of similar size or even larger (see Manta et al., 2002 and references therein; Yesilonis et al., 2008; Acosta et al., 2014; Curran-Cournane et al., 2015; Ljung et al., 2006). As such, besides perhaps the most intensely urbanized metropolitan areas, our findings are generalizable over large geographic regions with urban infrastructure.

In highly urbanized sites, heavy metal pollution is assumed traffic-derived (Pouyat et al. 2010, 2015; Chen et al., 2005, 2010; Yesilonis, 2008; Figuereido et al., 2009; Trammel et al., 2011; Zhao et al., 2016). Furthermore, Kuoppamäki et al. (2014) showed that metal concentrations in snow were clearly highest close to roads in the city of Lahti. As there were no major industrial plants that emit substantial amounts of heavy metals close to the 41 parks studied, we are confident that traffic was the major source of pollution in our study. The Pollution Index (PI) (the mean ratio of a heavy metal in a polluted area to that metal in a natural area) was high (PI $>3)$ for $\mathrm{Cu}$, and moderate $(1<\mathrm{PI} \leq 3)$ for $\mathrm{Pb}>\mathrm{Mn}>$ $\mathrm{Cr}>\mathrm{Ni}>\mathrm{Zn}$, indicating that all studied metals, except Fe, were enriched in urban park soils compared to background concentrations detected in the control forests.- These values correspond to those reported e.g. by Curran-Cournane et al. (2015) for Auckland, NZ and further suggesting that Lahti and Helsinki are at least moderately polluted by heavy metals originating, by and large, from traffic.

Below we discuss the influence of plant functional types and park age on pools of heavy metals and other elements and their mobility in park soils in southern Finland. To our knowledge, this is the first study in which heavy metal accumulation in urban soils has been tested in response to plant functional type per se using a thorough, replicated experimental design.

\subsection{Effects of plant functional groups and park age on heavy metal and tot-P pools}

We use pools $\left(\mathrm{g} \mathrm{m}^{-2}\right)$ and leached loads $\left(\mathrm{mg} \mathrm{m}^{-2}\right)$ of metals when describing metal accumulation and their mobility, respectively, in our park soils. This approach gives us an idea of the proportion of metals accumulated in the top soils that is potentially leachable.

Based on our previous findings (see Setälä et al., 2016) and results from other studies (Edmonson et al., 2014; Livesley et al., 2016), we hypothesized that divergent plant functional types; should differ in terms of their ability to accumulate elements, including heavy metals, in park soils. This assumption should particularly hold for evergreens, which produce slowly decomposable litter (Ponge, 2001; Bardgett and Wardle, 2010) and should thus gradually increase the accumulation of soil OM in urban parks (Setälä et al., 2016). Despite the clear influence of trees, 
especially evergreens, on various soil physical-chemical characteristics, such as lower soil pH and greater \%OM (Setälä et al., 2016), as well as lower soil bulk density and water content detected in this study, these effects did not consistently transfer to soil heavy metal pools. Yet, our results indicate that, compared to lawn, pools of $\mathrm{Cr}, \mathrm{Mn}$ and $\mathrm{Ni}$ tended to be lower under the two tree types, thus providing support to our first hypothesis. We did, however, expect a clearer relationship between plant functional types and heavy metal pools in urban parks, given that soil OM content is reported to not only bind metals in urban soils (Ge et al., 2000; Lair et al., 2007; Linde et al., 2007; Wong et al., 2006) but also reduce their mobility in urban soil profiles (Jones and Bryan, 1998; Sauve et al., 1998; Acousta et al., 2014). Indeed, we found weak but statistically significant positive correlations between \%OM and accumulation of heavy metals, especially $\mathrm{Pb}, \mathrm{Zn}$ and $\mathrm{Cu}$, in our park soils. It appears that the effect of, e.g. evergreens - even though producing soils with up to $5 \%$ units higher OM content than lawn soils in the intermediate and old parks (Setälä et al., 2016) - is inadequate to drive systematic differences in soil metal pools between the three plant types. This corroborates studies showing no relationship between \%SOM and heavy metal concentrations in urban greenspaces (Manta et al. 2002; Ljung et al., 2006; Salonen and Korkka-Niemi, 2007; Curran-Cournane et al., 2015). It is thus likely that organic matter content in urban greenspaces is too low to efficiently sorb heavy metals.

It is noteworthy thatmany of the metals were still sensitive to plant functional types judging by the often significant interactions between plant type and park age. For example, lawns in intermediate parks had the highest pools of $\mathrm{Cr}, \mathrm{Cu}, \mathrm{Fe}, \mathrm{Mn}, \mathrm{Ni}$, and $\mathrm{Zn}$, and in these, and older parks, pools of metals, except $\mathrm{Pb}$, proved to be lowest under evergreen trees. These findings further support our hypothesis that plant functional types can influence metal accumulation in urban park soils, although the effect appears context dependent. A clear example of this is the observation that metals were systematically the lowest under deciduous trees in young parks, whereas often the lowest under evergreen trees in intermediate and old parks. The reason for this is unclear but may relate to the high sand and low clay content, possibly due to management practices during planting. It is well known that soil mineral properties are important in defining contamination patterns in urban soils (Ljung et al., 2006; Norra et al., 2006; Pouyat et al., 2010). However, in the older parks typified by sandy loam and loamy sand soil, no correlation between soil texture and plant type was observed.

Because of more extended history of plant-soil interactions in the older parks, we hypothesized that their soils would be modified more than those in young parks and that these effects would be reflected in the retention of e.g. metals in the soil. Furthermore, we expected that young 
parks would accumulate less heavy metals than the older parks due to the much shorter time the former have been exposed to anthropogenic metal deposition. Indeed, metals in urban soils do increase with time (e.g., Chen et al., 2005; Guo et al., 2012; Pouyat et al., 2015; Wu et al., 2015), possibly because metals are immobile in the soil and may remain for extended periods of time (Ljung et al. 2006; Jumpponen and Jones, 2010). Our results corroborate these findings and support our hypothesis, i.e., pools of $\mathrm{Cu} \mathrm{Mn}, \mathrm{Pb}$ and $\mathrm{Zn}$ were, irrespective of plant type, lowest in young parks, while differences between the older parks were often small. It is likely that the low metal densities in young parks in our study are due to the short accumulation time of metals rather than divergent soil properties among parks of different ages. This is particularly evident for $\mathrm{Pb}$; soil pools were, on average, 3 times higher in old than young parks, which is likely because of the removal of lead from gasoline for over 20 years ago in Finland. However, accumulation time cannot explain the similar pool sizes of Fe, Cr, Mn, Ni and $\mathrm{Zn}$ in the young and old parks in our study.

Finally, we hypothesized that,- in young parks, metals deposited on the soil surface would not have had enough time to leach to the deeper soil layers, thus resulting in more pronounced differences in metal loads at different soil depths. Surprisingly, however, we often found the opposite, particularly in young parks where higher pools were observed in the deepest soil layer (e.g., Fe, Cr, Ni, Pb). This suggests that deeper soil layers in young parks were not removed during park construction, and that the new top soil had not been exposed to deposits. Furthermore, it actually seems that the top soil layers in old parks accumulate more metals (e.g., $\mathrm{Fe}, \mathrm{Cr}$, Ni, $\mathrm{Cu}$ ), which can be attributable to high accumulation and low mobilization of these and other heavy metals. Metals can move from soil surface into deeper soil layers in urban systems (Pouyat and McDonnell, 1991), but their concentrations are reduced (Turer et al., 2001; Pouyat and McDonnell, 1991) or not affected by soil depth (Yesilonis et al., 2008; Curran-Cournane et al., 2015). The often high density of urban soils due to trampling etc. can reduce infiltration of water, which reduces metal transport with water as well as metal absorption capacity (Tossavainen and Forsberg, 1999).

Overall, our results imply that plant functional types can, via modifying soils, influence the accumulation of metals in park soils, but this effect appears to depend on park age. However, this does not necessary imply that the ability of plant functional types to mobilize, e.g. heavy metals in their rhizospheres is insignificant. Next we explore the leachability of metals and nutrients in the park soils.

\subsection{Effects of plant functional groups and park age on heavy metal mobilisation}


We hypothesised that-the mobility (defined as the amount of water leachates entering the lysimeter vials) of metals and nutrient in park soils is also influenced by plant functional type and park age. However, our results provide little evidence that plant type and park age had consistent effects on the leachability of elements in the park soils. This is consistent with the lack of clear, overall impacts of plant types and park age on metal accumulation (pools) in our park soils. However, as with pools, plant type appeared to control element mobility in some cases, but this effect depended on park age. Importantly, when plant functional types affected the mobility of elements, this effect correlated with the mobility of water in the soils, emphasizing the crucial role of water as a carrier. In essence, when the mobility of water in the soils responded to plant type and park age - the mobility of metals responded in the same way. For example, the high leakage of water in soils under evergreen trees in young parks was associated with high loads of virtually all metals and nutrients. Similarly, the high mobility of water under lawns in intermediate parks resulted in high loads for $\mathrm{Fe}, \mathrm{Cr}, \mathrm{Cd}, \mathrm{Cu}, \mathrm{Ni}, \mathrm{N}$-forms, tot-P and DOC. Furthermore, the low mobility of water in the young park deciduous tree rhizospheres - compared to the other plant types in young parks - associated with the low mobility of practically all metals. These results imply that plant functional types controlled, at least to some extent, the leachability of water and thus the mobility of various metals in young and intermediate parks, but not in old parks. In old parks the amount of water that leached through the uppermost $15 \mathrm{~cm}$ soil layer was surprisingly even between the three plant types; however, most metals tended to be more mobile in evergreen soils compared to deciduous and lawn soils, possibly due to Although soil pH is one of the factors affecting the mobility of metals and other elements in the soil (Puls et al. 1991; Yoo and James 2002; Wong et al. 2007), the rather high pH (from 6 to 6.8 in all studied soils; Setälä et al., 2016) unlikely posed a significant influence on the mobility of metals in our parks soils (see Kennette et al., 2002; Wong et al., 2006).

We found evidence that some soil variables correlate with the mobility of water and elements in the parks soils. For example, soil moisture was the most important variable, being positively related to the mobility of water, most metals and tot-P. Given the importance of water as a carrier of metals in soils (Tossavainen and Forsberg, 1999), and the importance of water in affecting metals and some other elements in young and intermediate parks in the current study, it is not surprising that soil water content associated with the mobility of the selected elements. Similarly, soil organic matter content can influence the mobility of water and various elements in the soils, but unlike soil moisture, the effect should be negative (Jones and Bryan, 1998; Acosta et al., 2014). Indeed, we found that the leaching of water and some metals (Cu, $\mathrm{Fe}, \mathrm{Mn}, \mathrm{Pb}$, 
Va) were slightly and negatively correlated with \%OM in the soils. This is in accordance with the observed weak but positive correlation between soil OM content and soil metal pools (see above). However, the low correlations associated with soil moisture and organic matter content with the mobility of, e.g. heavy metals - the response of which appears to be metal-dependent - preclude broader generalizations of our results. It appears, thus, that these stressed anthropogenic systems experience altered ecosystem processes, as suggested by recent findings reporting the lack of correlation between heavy metal accumulation and soil organic matter content (Manta et al. 2002; Ljung et al., 2006; Salonen and Korkka-Niemi, 2007; Curran-Cournane et al, 2015) and soil pH (Manta et al., 2002; Wong et al., 2007).

Perhaps the most surprising result of our study was the minimal, if not completely lacking, influence of soil metal content on metal mobilisation. Even the unnaturally acute irrigation procedure at the end of the study seemed unable to flush metals or other elements (results for the separate rain events/irrigations not shown) from the system. Compared to the amount (pools, calculated per $\mathrm{m}^{-2}$ ) of metals detected in the uppermost $20 \mathrm{~cm}$ soils, the proportion mobilized $\left(\mathrm{m}^{-2}\right)$ from that layer was very low, being $\leq 0.01 \%$. This suggests that, despite the low clay $(13 \%$ across the soils) and OM (9.1\%) percentages, metals are strongly bound in urban park soils in southern Finland. It is possible that the extensive grass root layer under lawns, present in all studied parks under each plant type, effectively prevents metal leaching deeper in the soil profile (see Acousta et al., 2014). Interestingly, the mobility of $\mathrm{Va}$, As, Se and Be in the intermediate parks was not, in strong contrast to other metals and nutrients, responsive to the substantial amount of water leached through the lawn soils. The reason for this unexpected observation remains unclear.

Unlike metals, nutrients and soluble forms of C (such as DOC) are rather mobile in soils (Antoniadis and Alloway, 2002; McCracken et al., 2002) and expected to be more responsive to environmental variables in our study. Indeed, loads of $\mathrm{DOC}$ and $\mathrm{NO}_{3}-\mathrm{N}$ in the leachate - in contrast to any of the metals - were positively correlated with their soil pools. Similarly, load of DOC and tot-N, as well as tot-P, tended to be affected by soil bulk density, further suggesting that soil properties control nutrient and C flows in park soils. In addition, it appears that park (and tree) age controls $\mathrm{N}$ dynamics; virtually all of the $\mathrm{N}$ leached under evergreen trees in old parks was in the form of $\mathrm{NO}_{3}-\mathrm{N}$ while in the young parks, practically all $\mathrm{N}$ in the leachates was tot-N. However, in the two older parks the mobility of tot-N and tot-P, as well as NO3-N followed the same pattern observed for most of the heavy metals, suggesting that the vertical water flow was the most influential factor controlling their mobility in the uppermost $15 \mathrm{~cm}$ soil profile. 


\section{Conclusions}

Our study highlights the accumulation of metals in urban park soils. Although the direct effects of the plant functional types appear rather minimal, we posit that their direct control of the soil organic matter and $\mathrm{pH}$ are important drivers for the observed metal pool sizes and stocks.

Further, our data strongly suggest that the most important factor affecting element mobility in urban parks is the amount of water leached through the soils. That soil moisture was the strongest soil parameter affecting element loads in the lysimeter vials supports this conclusion. Importantly, water volume was almost significantly affected by plant traits suggesting that plant functional types have the potential to affect not only nutrient but also metal mobility in park soils. In summary, results show that urban parks soils have the potential to store e.g. metals and thus provide an important ecosystem service in polluted urbanized settings.

\section{Acknowledgements}

We thank Tuukka Ryynänen, Rauni Strömmer and Martin Romantschuck for help with field sampling. Satu Tegel, Tuuli Ylikotila and Pekka Engblom provided data for the parks in Helsinki, and Markku Saari provided information about parks in Lahti. The research was funded by an Academy of Finland grant (Grant number 268548).

\section{References}


Aarnio, P., Haaparanta S., Koskentalo T. 2002. Air quality in the Capital area in 2001. Publications by the City of Helsinki Environmental Center, No. 2002:17 (YTV). (In Finnish with English summary)

Acosta, J.A., Faz, A., Martinez-Martnez, S., Arocena, J.M. 2014. Grass-induced changes in properties of soils in urban green areas with emphasis on mobility of metals. J Soils Sediments $14,819-828$

Allison, S.D. (2006). Brown ground: a soil carbon analogue for the green world hypothesis? Am. Nat. 167, 619-627.

Amato, F., Pandolfi, M., Escrig, A., Querol, X., Alastuey, A., Pey, J., Perez, N., Hopke, P.K., 2009. Quantifying road dust resuspension in urban environment by Multilinear Engine: a comparison with PMF2. Atmospheric Environment 43, 2770-2780.

Antoniadis, V., Alloway, B.J., 2002. The role of dissolved organic carbon in the mobility of Cd, Ni and Zn in sewage sludge-amended soils. Environmental Pollution 117, 515-521.

Bardgett, R.D., and Wardle, D.A. (2010). Above-ground-Belowground linkages. Biotic Interactions, Ecosystem Processes and Global Change. New York: Oxford University Press.

Bieby, V.T., Siti. R.S.A., Hassan, B., Mushrifah, I., Nurina, A., 2011. Review on Heavy Metals (As, Pb, and Hg) Uptake by Plants through Phytoremediation. International Journal of Chemical Engineering. Volume 2011, Article ID 939161, 31 pp. http://dx.doi.org/10.1155/2011/939161

Brown, S., Chaney, R.L., Hallfrisch, J.G., Xue, Q., 2003. Effects of biosolids processing on lead bioavailability in an urban soil. J. Environ. Qual. 32, 100-108

Buol, S.W., Southard, R.J., Graham, R.C., McDaniels, P.A., 2011. Soil genesis and classification, 6th edn. Wiley, New York, 560 pp.

Callender, E., Rice, K.C., 2000. The urban environmental gradient: anthropogenic influences on the spatial and temporal distributions of lead and zinc in sediments. Environmental Science and Technology 34, 232-238.

Chen, T.B., Zheng, Y.M., Lei, M., Huang, Z.C., Wu, H.T., Chen, H., Fan, K.K., Yu, K., Wu, X., Tian, Q.Z., 2005. Assessment of heavy metal pollution in surface soils of urban parks in Beijing, China. Chemosphere 60, 542-51. 
Colpaert, J.V., Wevers, J.H.L., Krznaric, E., Adriaensen, K., 2011. How metal-tolerant ecotypes of ectomycorrhizal fungi protect plants from heavy metal pollution. Annals of Forest Science 68, 17-24.

Couling, N.R., Towell, M.G., Semple, K.T., 2010. Biodegradation of PAHs in soil: Influence of chemical structure, concentration and multiple amendment. Environmental Pollution 158, 3411-3420.

Curran-Cournane, F., Lear, G., Schwendenmann, L., Khin, J., 2015. Heavy metal soil pollution is influenced by the location of green spaces within urban settings. Soil Research 53, 306-315.

Davis, A. P., Shokouhian, M., Ni, S., 2001. Loading estimates of lead, copper, cadmium, and zinc 624 in urban runoff from specific sources. Chemosphere 44, 997-1009.

Edmondson, J.L., Davies, Z.G., McCormack, S.A., Gaston, K.J., Leake, J.R. (2014a). Land-cover effects on soil organic carbon stocks in a European city. Science of the Total Environment 472, 444-453. http://dx.doi.org/10.1016/j.scitotenv.2013.11.025

Edmondson, J.L., O’Sullivan, O.S., Inger, R., Potter, J. McHugh, N., Gaston, K.J., et al. (2014b). Urban tree effects on soil organic carbon. PLoSONE 9:e101872. doi:10.1371/journal.pone.0101872,

Elless, M.P., Bray, C.A., Blaylock, M.J., 2007. Chemical behavior of residential lead in urban yards in the United States. Environmental Pollution 148, 291-300. doi: 10.1016/j.envpol.2006.10.024

Figueiredo, A.M.G., Enzweiler, J., Camargo, S.P., Sígolo, J.B., Gumiero, F.C., Pavese, A.C., Milian, F.M., 2009. Metal contamination in urban park soils of São Paulo. Journal of Radioanalytical and Nuclear Chemistry 280, 423-429. DOI: 10.1007/s10967-009-0538-0

Forsius, M., Anttila, S., Arvola, L., Bergström, I., Hakola, H., Heikkinen, H.I., et al. (2013). Impacts and adaptation options of climate change on ecosystem services in Finland: a model based study. Current Opinion in Environmental Sustainability 5, 26-40. doi: http://dx.doi.org/10.1016/j.cosust.2013.01.001

Franzluebbers A.J., 2002. Soil organic matter stratification ratio as an indicator of soil quality. Soil Tillage Res. 66, 95-106.

Ge, Y., Murray, P., Hendershot, W.H., 2000. Trace metal speciation and bioavailability in urban soils. environmental Pollution 107, $137-144$.

Golubiewski N.E. (2006). Urbanization increases grassland carbon pools: effects of landscaping in Colorado's front range. Ecol. Appl. 16, 55571. 
Jones, M.N., and Bryan, N.D., 1998. Colloidal properties of humic substances. Advances in Colloid and Interface Science 78, 1-48.

Jumpponen, A., Jones, K.L., 2010. Seasonally dynamic fungal communities in the Quercus macrocarpa phyllosphere differ between urban and nonurban environments. New Phytologist 186, 496-513. DOI: 10.1111/j.1469-8137.2010.03197.x

Kennette, D., Hendershot, W., Tomlin, A., Sauve', S., 2002. Uptake of trace metals by the earthworm Lumbricus terrestris L. in urban contaminated soils. Applied Soil Ecology 19, 191-198.

Kohonen, T., Salminen, R., 1993. Sammalen ja humuksen alkuainepitoisuudet Rikki- ja raskasmetallilaskeuman indikaattoreina Turun kaupungin alueella. Turun kaupunki, ympäristönsuojelutoimisto, Julkaisu 4/93.

Kuoppamäki, K., Setälä, H., Rantalainen, A-L, Kotze, D.J. 2014. Urban snow indicates pollution originating from road traffic. Environmental Pollution 195, 56-63.

Lair, G.J., Gertzabek, M.H., Haberhauer, G. 2007. Sorption of heavy metals on organic and inorganic soil constituents. Environ. Chem. Lett. 5, 23-27.

Lal, R. (2004). Soil carbon sequestration to mitigate climate change. Geoderma 123, 1-22.

Lehmann A., and Stahr K. (2007). Nature and significance of anthropogenic urban soil. J. Soils Sediments 7, 247-60.Ljung, K., Selinus, O., Otabbong, E., 2006. Metals in soils of children's urban environments in the small northern European city of Uppsala. Science of the Total Environment 366, 749-759.

Liveslay, S.J., Ossola, A., Threlfall, C.G., Hahs, A.K., Williams, N.S.G., 2016. Soil carbon and carbon/nitrogen ratio change under tree canopy, tall grass, and turf grass areas of urban green space. J. Environ. Qual. 45, 215-223.

Manta, D.S., Angelone, M., Bellanca, A., Neri, R., Sprovieri, M., 2002. Heavy metals in urban soils: a case study from the city of Palermo (Cicily), Italy. The Science of the Total Environment 300, 229-243.

McCracken, K.L., McDowell, W.H., Harter, R.D., Evans, C.V., 2002. Dissolved Organic Carbon Retention in Soils: Comparison of Solution and Soil Measurements. Soil Sci. Soc. Am. J. 66, 563-568.

McGrath, S.P., Zhao, F.J., 2003. Phytoextraction of metals and metalloids from contaminated soils. Curr Opin Biotechnol.14, $277-82$. 
Nan, H., Jumpponen, A., Francini, G., Kotze, D.J., Liu, X., Romantschuk, M., Strömmer, R., Setälä, H., 2017. Soil microbial communities are shaped by vegetation type and park age in cities under cold climate. Environmental Microbiology (in press)

Norra, S., Lanka-Paditha, M., Kramar, U., Stuben, D., 2006. Mineralogical and geochemical paterns of urban surface soils, the example of Pfortzheim, German. Appl. Geochem. 21, 2064-2081.

Ossola, A., Hahs, A.K., and Livesley, S.J. (2015). Habitat complexity influences fine scale hydrological processes and the incidence of stormwater runoff in managed urban ecosystems. J. Environ. Manage 159, 1-10. doi:10.1016/j. jenvman.2015.05.002.

Öztürk,M., Özözen, G., Minareci, O., 2009. Determination of heavy metals in fish, water and sediments of Avsardam dam lake in Turkey. Minareci Journal of Environmental Health Science \& Engineering 6, 73-80.

Ponge, J-F. (2003). Humus forms in terrestrial ecosystems: a framework to biodiversity. Soil Biol. Biochem. 35, 935-945.

Pouyat, T.V., McDonnell, M.J., 1991. Heavy metal accumulation in forest soils along an urban-rural gradient in southeastern New Yourk, USA. Water,Air and Soil Pollution 57-58, 797-807.

Pouyat, R. V., Yesilonis, I., Golubiewski, N. (2009). A comparison of soil organic carbon stocks between residential turf grass and native soil. Urban Ecosystems 12, 45-62.

Pouyat, R.V., Szlavecz, K., Yesilonis, I.D., Groffman, P.M., Schwarz, K. (2010). Chemical, physical, and biological characteristics of urban soils. In: J. Aitkenhead-Peterson, Volder, A.n(Eds.), Urban ecosystem ecology. Agronomy Monograph 55, 119-152.

Pouyat, R.V., Szlavecz, K., Yesilonis, I.D., Wong, C.P., Murawski, L., Marra, P., Casey, R.E., Lev, S., 2015. Multi-scale assessment of metal contamination in residential soil and soil fauna: A case study in the Baltimore-Washington metropolitan region, USA. Landscape and Urban Planning 142, 7-17.

Puls, R.W., Powell, R.M., Clark, D., Cynthia, Eldred, C.J., 1991. Effects of pH, solid/solution ratio, ionic strength, and organic acids on Pb and Cd sorption on kaolinite. Water, Air, and Soil Pollution 57, 423-430.

R Core Team, 2013. R: a Language and Environment for Statistical Computing. R Foundation for Statistical Computing, Vienna, Austria. http:// www.R-project. org/.Core Team, 2016. 
Rabito, F.E., Shorter, C., White, L.E., 2003. Lead levels among children who live in public housing. Epidemiology 14, $263-268$.

Raciti, S.M., Groffman, P.M., Jenkins, J.C., Pouyat, R.V., Fahey, T.J., Pickett, S.T.A., Cadenasso, M.L. (2011). Accumulation of carbon and nitrogen in residential soils with different land use histories. Ecosystems. 14, 287-297.

Reganold, J.P., Palmer, A.S., 1995. Significance of gravimetric versus volumetric measurements of soil quality under biodynamic, conventional, and continuous grass management. Journal of Soil and Water Conservation 50, 298-305.

Reid, B.J., Jones, K.C., Semple, K.T., 2000. Bioavailability of persistent organic pollutants in soils and sediments - a perspective on mechanisms, consequences and assessment. Environmental Pollution, 108, 103-112.

Ruuth, J. Toivanen, H., Kuhmonen, I., Leppänen, E., Kiljunen, A. (2016) Kanta- ja Päijät-Hämeen ilmanlaadun bioindikaattorit vuonna 2014. Raportteja 6/2016. Hämeen elinkeino-, liikenne- ja ympäristökeskus. 154 p. ISBN 978-952-314-394-4 (PDF)

Salminen, R., 1995. Alueellinen geokemiallinen kartoitus Suomessa vuosina 1982 - 1994. Summary: Regional Geochemocal Mapping in Finland in 1982 - 1994. Geol. Surv. Finland, Rep. Investig. 130.

Salla, A., 1999. Background levels of harmful substances in the soils of Helsinki. Publications by the city of Helsinki Environment Centre, No. 15/99. (In Finnish with English summary).

Salminen, R., Kukkonen, M., Paukola, T., Töllikkö, S., 1997. Chemical composition of clays in southwestern Finland. Geol. Surv. Finland Spec. Paper 23, 117-126.

Salonen, V-P., Korkka-Niemi, K., 2007. Influence of parent sediments on the concentration of heavy metals in urban and suburban soils in Turku, Finland. Applied Geochemistry 22, 906-918.

Sauve, S., McBride, M.B., Hendershot. W.H., 1998. Lead phosphate solubility in water and soil suspensions. Environ. Sci. Technol. 32, $388-393$.

Setälä H., Birkhofer, K., Brady, M., Byrne, L., Holt, G., de Vries, F., et al. (2014). Urban and agricultural soils: Conflicts and trade-offs in the optimization of ecosystem services. Urban Ecosyst. 17, 239-253.

Setälä, H., Francini, G., Allen, J.A., Nan, H., Jumpponen, A., Kotze, D.J., 2016. Plant functional traits and park age influence soils and soilderived ecosystem services in urban parks under cold climate. Frontiers in Ecology and Evolution 4, 1-12. doi: 10.3389/fevo.2016.00093 
Taka, M., Warsta, L., Niemi, T., Sillanpää, N., Valtanen, M., Kuoppamäki, K., Kokkonen, T., Setälä, H., 2017. Spatio-temporal patterns of major ions in cold climate urban stormwater. Hydrological Processes, in press.

Tao, Y., Yuan, Z., Xiaona, H., Wei, M., 2012. Distribution and bioaccumulation of heavy metals in aquatic organisms of different trophic levels and potential health risk assessment from Taihu lake, China Ecotoxicology and Environmental safety 81, 55-64.

Thornton, I., 1991. Metal contamination in urban areas. In: Bullock P, (Ed.), Soils in the urban environment. Cambridge University Press, pp. 4775.

Tossavainen, M., Forsberg, E., 1999. The potential leachability from natural road construction materials. The Science of the Total Environment 239, 31-47.

Trammell, T.L.E., Schneid, B.P., Carreiro, M.M., 2011. Forest soils adjacent to urban interstates: soil physical and chemical properties, heavy metals, disturbance legacies, and relationships with woody vegetation. Urban Ecosystems 14, 525-552. doi: 10.1007/s11252-011-0194-3

Turer, D., Maynard, J.B., Sansalone, J., 1991. Heavy metal contamination in soils of urban highways: comparison between runoff and soil concentrations at Cincinnati, Ohio. Water, Air, and Soil Pollution 132, 293-314.

Valtanen, M., Sillanpää, N., Setälä, H. (2014). The effects of urbanization on runoff pollutant concentrations, loadings and their seasonal patterns under cold climate. Water, Air, Soil Pollut. 225:1977.

Valtanen, M. P., Sillanpää, N., Setälä, H. M., 2015. Key factors affecting urban runoff pollution under cold climatic conditions. Journal of Hydrology 529, 1578-1589.

Wall, D.H., Nielsen, U.N., Six, J. 2015. Soil biodiversity and human health. Nature 528, 69-76. doi:10.1038/nature15744

Yesilonis, I.D., Pouyat, R.V., Neerchal, N.K., 2008. Spatial distribution of metals in soils in Baltimore, Maryland: Role of native parent material, proximity to major roads, housing age and screening guidelines. Environmental Pollution 156, 723-731.

Yong, R.N., Mohamed, A.M.O., Warkentin, B.P., 1992. Principles of contamination transport in soils. Elsevier, New York.

Yoo, M.S., James, B.R. 2002. Zinc extractability as a function of pH in organic waste-amended soils. Soil Science 167, $246-259$.

Wardle, D.A. (2002). Communities and ecosystems: linking the aboveground and belowground processes. Monographs in population biology, 34. Princeton, NJ: Princeton University Press. 
Wong, C.S.C., Li, X., Thornton, I., 2006. Urban environmental geochemistry of trace metals. Environmental Pollution 142, 1-16.

Wong J.W.C., Li K.L., Zhou L.X., Selvam A. 2007. The sorption of Cd and Zn by different soils in the presence of dissolved organic matter from sludge. Geoderma 137, 310-317.

\section{Figure, Table and Supplementary Material legends}

Figure 1. The effects of plant functional type and park age on soil properties and pools $\left(\mathrm{g} \mathrm{m}^{-2}\right)$ of heavy metals and tot-P. Predicted mean $\pm \mathrm{SE}$ values are presented.

Figure 2. The effects of plant functional type and park age on the volume of water leached through the soils ( $\mathrm{ml})$ and loads $\left(\mathrm{mg} \mathrm{m}^{-2}\right)$ of heavy metals, dissolved organic carbon (DOC), tot-N and tot-P. Predicted mean \pm SE values are presented.

Table 1. GLMM results, testing the effects of plant functional type (evergreen trees, deciduous trees, lawns), park age (young, intermediate, old), soil depth $(0-10,11-20$, and $21-50 \mathrm{~cm})$ and their two-way and three-way interactions of various soil properties and elements. Coefficients (SE) and $p$-values are presented. Significant effects $(\mathrm{p}<0.1)$ are highlighted in bold. The evergreen tree functional group, young age park, and shallow soil depth treatment levels are in the intercept. Significant interaction terms are indicated with an asterisk.

Table 2. GLMM results (log-normal models), testing the effects of plant functional type, park age, their interaction and \% clay, bulk density (Bulk Dens), \% soil moisture (\% Moist), $\mathrm{pH}, \%$ organic matter $(\% \mathrm{OM})$, concentration of that element in the soil ([] in soil) on various elements in the lysimeter leachate. Coefficients, standard errors (in brackets) and p-values are presented. Significant $p$-value $\leq 0.1$ are indicated in bold.

Evergreen trees in young parks are in the intercept. 
Supplementary Material, Fig. S1. Plots presenting the responses of bulk density, soil texture, \% soil moisture, soil metals and tot-P to plant functional type, park age and depth.

Supplementary Material, Fig. S2. Plots presenting the responses of bulk density, \% soil moisture, soil metals and tot-P to plant functional type (evergreen and broadleaf trees) between old Lahti parks and control forests. Abbreviations: $\mathrm{E}=$ evergreen, $\mathrm{B}=$ broadleaf, control = control forests, park $=$ park sites.

Supplementary Material, Fig. S3. Correlations between SOM and the concentrations of various soil elements (top figures), and pH and the concentrations of various soil elements (bottom figures).

Supplementary Material, Table S1. Concentrations of elements ( $\mathrm{mg} / \mathrm{kg} \mathrm{dw}$ ) in the park and control soils. Mean values and standard errors (SE) are presented.

Supplementary Material, Table S2. Linear model results, testing the effects of vegetation type (a four-level factor including natural evergreen forest [in the intercept], park evergreen trees [treatcon.park], natural deciduous forest [treatlin.con] and park deciduous trees [treatlin.park]), sample depth (a two-level factor including 0-10 cm [in the intercept] and 11-20 cm [depth.F2]), and their interaction. The interaction term was removed if non-significant ( $\mathrm{p}$-value $>0.1$ ). Two analyses were performed per element (except Bulk Density and \% Soil moisture), one on elemental concentration in the soil, and one on pools in the soil.

Supplementary Material, Table S3. GLMM results (binomial models), testing the effects of plant functional type, park age, their interaction and $\%$ clay, bulk density (Bulk Dens), \% soil moisture (\% Moist), pH, \% organic matter (\%OM), concentration of that element in the soil ([] in soil) on various elements in the lysimeter leachate. Coefficients, standard errors (in brackets) and p-values are presented. Significant $p$-value $\leq 0.1$ are 
indicated in bold. Evergreen trees in young parks are in the intercept. Some elements produced the same results since they were present/absent in the exact same leachate samples. 
Supplementary Material, Table S3. GLMM results (binomial models), testing the effects of plant functional type, park age, their interaction and $\%$ clay, bulk density (Bulk Dens), \% soil moisture (\% Moist), $\mathrm{pH}, \%$ organic matter (\%OM), concentration of that element in the soil (Cons in soil) on various elements in the lysimeter leachate. Coefficients, standard errors (in brackets) and p-values are presented. Significant $p$-value $\leq$ 0.1 are indicated in bold. Evergreen trees in young parks are in the intercept. Some elements produced the same results since they were

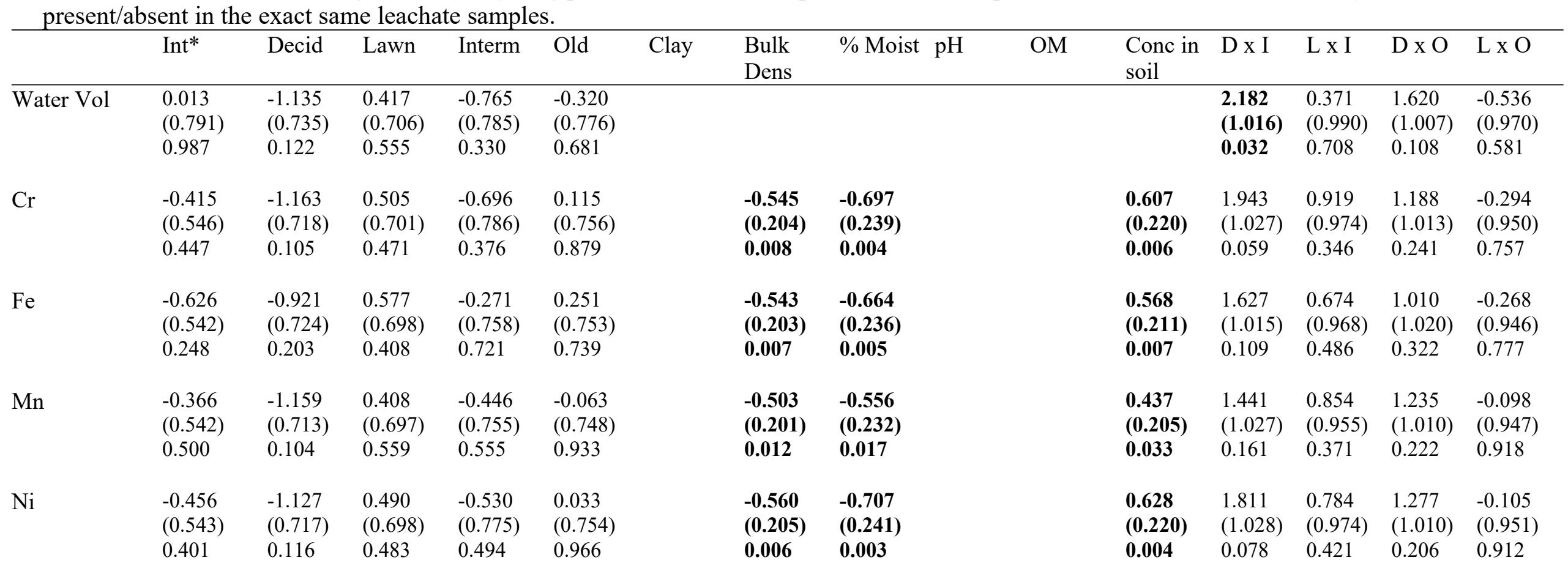




$\begin{array}{lllll}-0.717 & -1.002 & 0.345 & -0.106 & 0.280 \\ (0.661) & (0.717) & (0.702) & (0.766) & (0.756) \\ 0.278 & 0.162 & 0.623 & 0.890 & 0.712\end{array}$

$\begin{array}{ll}-0.456 & -0.419 \\ (0.210) & (0.241) \\ 0.030 & 0.082\end{array}$

Zinc, Copper, Cadmium

$\begin{array}{lllllll}-0.497 & -1.283 & 0.543 & -0.328 & 0.070 & \mathbf{- 0 . 4 2 7} & \mathbf{- 0 . 4 7 2} \\ (0.636) & (0.717) & (0.693) & (0.756) & (0.747) & \mathbf{( 0 . 2 0 6 )} & \mathbf{( 0 . 2 4 0 )} \\ 0.435 & 0.074 & 0.434 & 0.664 & 0.926 & \mathbf{0 . 0 3 8} & \mathbf{0 . 0 4 9}\end{array}$

Aluminium, Cobalt, Vanadium, Arsenic, Selenium, Beryllium $\begin{array}{lllll}1.698 & -1.372 & -1.666 & -1.799 & -1.549\end{array}$

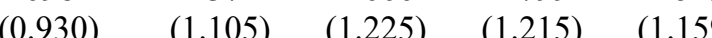
0.068 $0.214 \quad 0.174$

$(1.215)$

0.182

\subsection{4}

(0.364)

$\mathbf{- 0 . 7 3 5}$

$-\mathbf{0 . 8 8 2}$

$<\mathbf{0 . 0 0 1}$

0.028

$(0.347)$

0.011

\begin{tabular}{|c|c|c|c|c|c|c|c|c|}
\hline DOC & $\begin{array}{l}-1.827 \\
(0.796) \\
0.022\end{array}$ & $\begin{array}{l}-1.294 \\
(0.929) \\
0.164\end{array}$ & $\begin{array}{l}0.300 \\
(0.806) \\
0.710\end{array}$ & $\begin{array}{l}-1.936 \\
(1.106) \\
0.080\end{array}$ & $\begin{array}{l}-1.089 \\
(1.042) \\
0.296\end{array}$ & $\begin{array}{l}0.461 \\
(0.267) \\
0.084\end{array}$ & & $\begin{array}{l}-0.590 \\
(0.299) \\
0.049\end{array}$ \\
\hline tot-P & $\begin{array}{l}-0.497 \\
(0.636) \\
0.435\end{array}$ & $\begin{array}{l}-1.283 \\
(0.717) \\
0.074\end{array}$ & $\begin{array}{l}0.543 \\
(0.693) \\
0.434\end{array}$ & $\begin{array}{l}-0.328 \\
(0.756) \\
0.664\end{array}$ & $\begin{array}{l}0.070 \\
(0.747) \\
0.926\end{array}$ & & $\begin{array}{l}-0.427 \\
(0.206) \\
0.038\end{array}$ & $\begin{array}{l}-0.472 \\
(0.240) \\
0.049\end{array}$ \\
\hline
\end{tabular}

$\begin{array}{llll}1.522 & 1.003 & 1.194 & -0.143 \\ (1.019) & (0.970) & (1.008) & (0.952) \\ 0.135 & 0.301 & 0.237 & 0.881\end{array}$

$\begin{array}{llll}1.840 & 0.831 & 1.456 & -0.343\end{array}$

$\begin{array}{llll}(1.016) & (0.961) & (1.006) & (0.945)\end{array}$

$\begin{array}{llll}0.070 & 0.387 & 0.148 & 0.717\end{array}$

$\begin{array}{llll}1.293 & 3.099 & 0.883 & 0.265\end{array}$

$\begin{array}{llll}(1.596) & (1.675) & (1.563) & (1.637)\end{array}$

$\begin{array}{llll}0.418 & 0.064 & 0.572 & 0.871\end{array}$

$\begin{array}{llll}2.649 & 1.126 & \mathbf{2 . 9 3 0} & -1.562\end{array}$

$\begin{array}{llll}(\mathbf{1 . 3 9 7}) & (1.254) & \mathbf{( 1 . 3 9 3}) & \text { (1.358) }\end{array}$

$\begin{array}{llll}\mathbf{0 . 0 5 8} & 0.369 & \mathbf{0 . 0 3 5} & 0.250\end{array}$

$\begin{array}{llll}1.840 & 0.831 & 1.456 & -0.345\end{array}$

$\begin{array}{llll}(1.016) & (0.961) & (1.006) & (0.945)\end{array}$

$\begin{array}{llll}0.070 & 0.387 & 0.148 & 0.717\end{array}$

* Abbreviations: Int = Model intercept, Decid or $\mathrm{D}=$ deciduous trees, Interm or I = intermediately aged parks, $\mathrm{L}=$ lawn, $\mathrm{O}=$ old parks. 


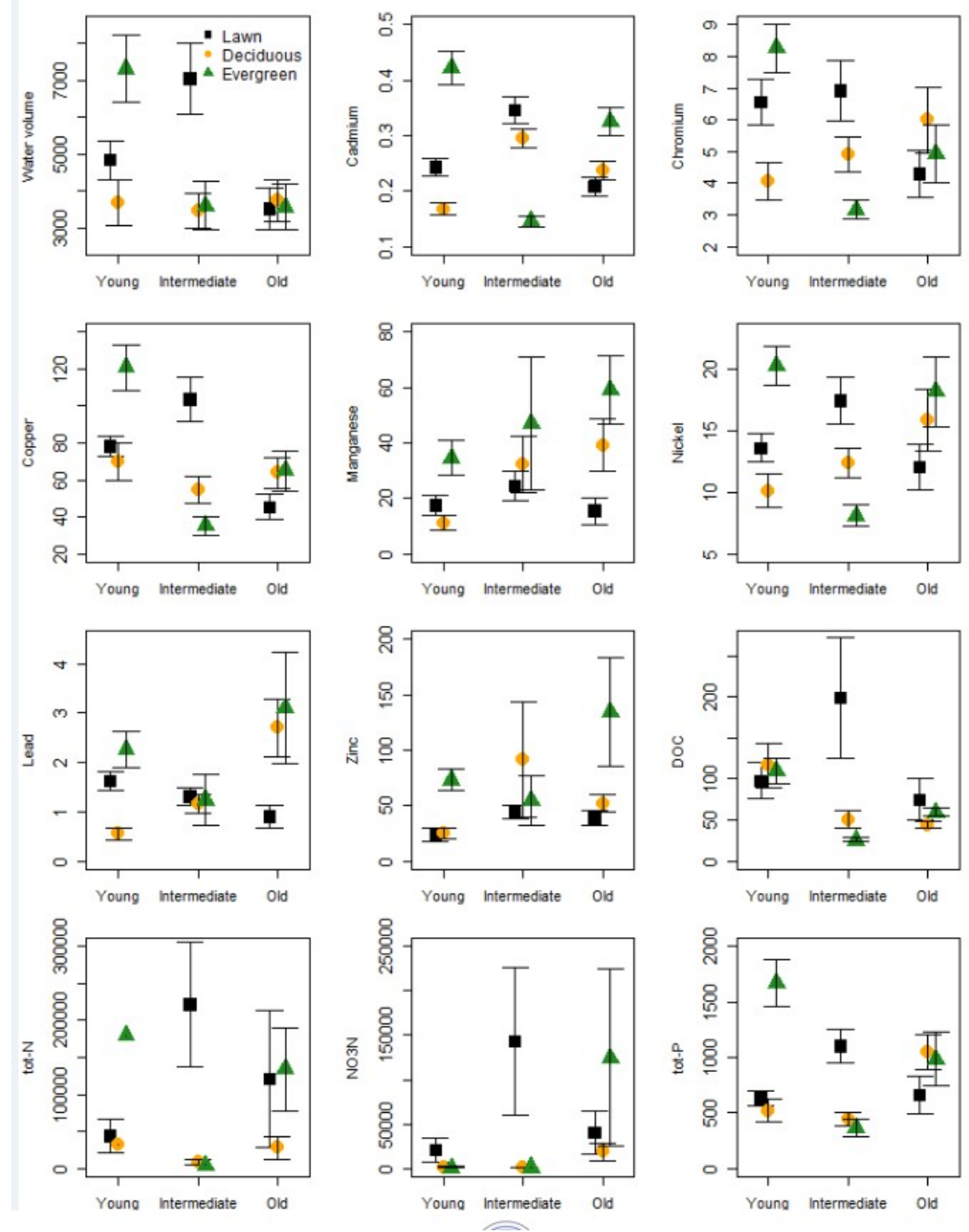

Fig. 2 

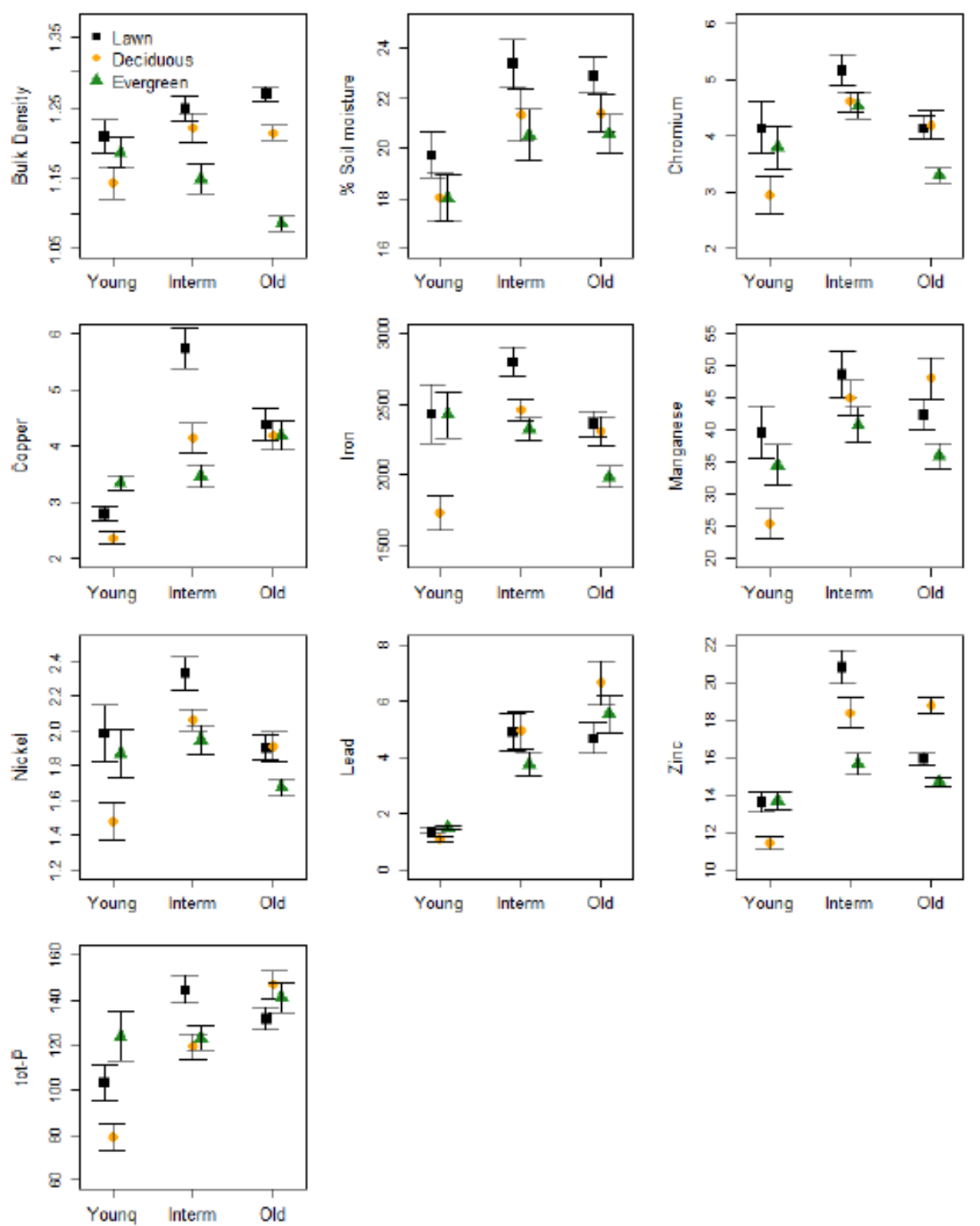

$792 \quad$ Fig. 1 
Table 1. GLMM results, testing the effects of plant functional type (evergreen trees, deciduous trees, lawns), park age (young, intermediate, old), soil depth $(0-10,11-20$, and $21-50 \mathrm{~cm})$ and their two-way and three-way interactions of various soil properties and elements. Coefficients (SE) and $\mathrm{p}$-values are presented. Significant effects $(\mathrm{p}<0.1)$ are highlighted in bold. The evergreen tree functional group, young age park, and shallow soil depth treatment levels are in the intercept. Significant interaction terms are indicated with an asterisk.

\begin{tabular}{|c|c|c|c|c|c|c|c|c|c|c|c|}
\hline Variable & Intercept & Deciduous & Lawn & Interm & Old & Depth 2 & Depth 3 & $\begin{array}{l}\text { Functional } \\
\text { group x Age }\end{array}$ & $\begin{array}{l}\text { Functional } \\
\text { group } \mathrm{x} \\
\text { Depth }\end{array}$ & $\begin{array}{l}\text { Age } x \\
\text { Depth }\end{array}$ & $\begin{array}{l}\text { Functional } \\
\text { group x Age } \\
\text { x Depth }\end{array}$ \\
\hline$\overline{\text { Bulk }}$ & 1.081 & -0.021 & 0.041 & 0.022 & 0.007 & 0.082 & 0.180 & * & & $*$ & \\
\hline \multirow{2}{*}{ Density } & $(0.057)$ & $(0.053)$ & $(0.052)$ & $(0.075)$ & $(0.075)$ & $(0.047)$ & $(\mathbf{0 . 0 5 0})$ & & & & \\
\hline & $<0.001$ & 0.693 & 0.432 & 0.768 & 0.926 & 0.082 & $<0.001$ & & & & \\
\hline \multirow[t]{3}{*}{ Sand (\%) } & 76.282 & 0.184 & -5.338 & -8.158 & -5.754 & -5.705 & -3.237 & $*$ & & & * \\
\hline & $(7.283)$ & (3.439) & $(3.385)$ & (4.396) & $(4.431)$ & (3.375) & $(3.378)$ & & & & \\
\hline & $<0.001$ & 0.957 & 0.115 & 0.063 & 0.194 & 0.091 & 0.338 & & & & \\
\hline \multirow[t]{3}{*}{ Silt (\%) } & 3.556 & 0.119 & 0.380 & 0.633 & 0.715 & 0.564 & 0.375 & $*$ & $*$ & $*$ & $*$ \\
\hline & $(0.511)$ & $(0.267)$ & $(0.265)$ & $(0.310)$ & $(0.311)$ & $(0.266)$ & $(0.266)$ & & & & \\
\hline & $<0.001$ & 0.655 & 0.152 & 0.041 & 0.022 & 0.034 & 0.159 & & & & \\
\hline \multirow[t]{3}{*}{ Clay (\%) } & 3.044 & 0.009 & 0.167 & 0.600 & 0.255 & 0.066 & -0.119 & & & $*$ & \\
\hline & $(0.455)$ & $(0.116)$ & $(0.114)$ & $(0.306)$ & $(0.310)$ & $(0.178)$ & $(0.194)$ & & & & \\
\hline & $<0.001$ & 0.938 & 0.143 & 0.050 & 0.412 & 0.712 & 0.540 & & & & \\
\hline \multirow[t]{3}{*}{ Moist (\%) } & 21.783 & 0.913 & 2.403 & 3.360 & 1.859 & -4.183 & -9.316 & & & $*$ & \\
\hline & $(1.342)$ & $(0.695)$ & $(0.678)$ & (1.771) & (1.788) & (1.057) & (1.159) & & & & \\
\hline & $<0.001$ & 0.189 & $<0.001$ & 0.058 & 0.299 & $<0.001$ & $<0.001$ & & & & \\
\hline \multirow[t]{3}{*}{$\mathrm{Cr}$} & 0.877 & 0.091 & 0.326 & 0.524 & 0.337 & 0.257 & 0.307 & & $*$ & $*$ & $*$ \\
\hline & $(0.277)$ & $(0.149)$ & $(0.147)$ & $(0.190)$ & (0.191) & $(0.142)$ & $(0.142)$ & & & & \\
\hline & 0.002 & 0.541 & 0.026 & 0.006 & 0.078 & 0.070 & 0.031 & & & & \\
\hline
\end{tabular}




\begin{tabular}{|c|c|c|c|c|c|c|c|c|c|c|c|}
\hline $\mathrm{Cu}$ & $\begin{array}{l}1.124 \\
(0.204) \\
<0.001\end{array}$ & $\begin{array}{l}-0.218 \\
(0.115) \\
0.059\end{array}$ & $\begin{array}{l}-0.110 \\
(0.111) \\
0.320\end{array}$ & $\begin{array}{l}0.095 \\
(0.151) \\
0.529\end{array}$ & $\begin{array}{l}0.219 \\
(0.153) \\
0.152\end{array}$ & $\begin{array}{l}0.052 \\
(0.057) \\
0.364\end{array}$ & $\begin{array}{l}-0.039 \\
(0.030) \\
0.508\end{array}$ & $*$ & & & \\
\hline $\mathrm{Fe}$ & $\begin{array}{l}7.535 \\
(0.199) \\
<0.001\end{array}$ & $\begin{array}{l}-0.143 \\
(0.088) \\
0.103\end{array}$ & $\begin{array}{l}0.044 \\
(0.084) \\
0.602\end{array}$ & $\begin{array}{l}0.163 \\
(0.138) \\
0.237\end{array}$ & $\begin{array}{l}0.082 \\
(0.139) \\
0.554\end{array}$ & $\begin{array}{l}0.098 \\
(0.074) \\
0.184\end{array}$ & $\begin{array}{l}0.173 \\
(\mathbf{0 . 0 7 9}) \\
\mathbf{0 . 0 2 8}\end{array}$ & $*$ & & $*$ & \\
\hline $\mathrm{Mn}$ & $\begin{array}{l}3.138 \\
(0.311) \\
<0.001\end{array}$ & $\begin{array}{l}0.011 \\
(0.160) \\
0.943\end{array}$ & $\begin{array}{l}0.421 \\
(0.158) \\
0.008\end{array}$ & $\begin{array}{l}\mathbf{0 . 4 3 9} \\
(\mathbf{0 . 1 9 5}) \\
\mathbf{0 . 0 2 4}\end{array}$ & $\begin{array}{l}0.441 \\
(0.196) \\
0.025\end{array}$ & $\begin{array}{l}0.241 \\
(0.153) \\
0.116\end{array}$ & $\begin{array}{l}0.231 \\
(0.153) \\
0.131\end{array}$ & $*$ & $*$ & & $*$ \\
\hline $\mathrm{Ni}$ & $\begin{array}{l}0.279 \\
(0.206) \\
0.175\end{array}$ & $\begin{array}{l}0.004 \\
(0.121) \\
0.973\end{array}$ & $\begin{array}{l}0.253 \\
(0.120) \\
0.035\end{array}$ & $\begin{array}{l}0.264 \\
(0.151) \\
0.080\end{array}$ & $\begin{array}{l}0.281 \\
(0.152) \\
0.064\end{array}$ & $\begin{array}{l}0.250 \\
(0.160) \\
0.031\end{array}$ & $\begin{array}{l}0.280 \\
(0.116) \\
0.016\end{array}$ & & $*$ & $*$ & $*$ \\
\hline $\mathrm{Pb}$ & $\begin{array}{l}0.096 \\
(0.416) \\
0.817\end{array}$ & $\begin{array}{l}-0.102 \\
(0.155) \\
0.510\end{array}$ & $\begin{array}{l}-0.087 \\
(0.147) \\
0.554\end{array}$ & $\begin{array}{l}1.076 \\
(0.256) \\
<0.001\end{array}$ & $\begin{array}{l}1.346 \\
(0.258) \\
<0.001\end{array}$ & $\begin{array}{l}0.018 \\
(0.129) \\
0.888\end{array}$ & $\begin{array}{l}0.378 \\
(0.138) \\
0.006\end{array}$ & $*$ & & $*$ & \\
\hline tot-P & $\begin{array}{l}4.735 \\
(0.119) \\
<0.001\end{array}$ & $\begin{array}{l}-0.261 \\
(0.108) \\
0.016\end{array}$ & $\begin{array}{l}0.019 \\
(0.102) \\
0.850\end{array}$ & $\begin{array}{l}0.144 \\
(0.167) \\
0.387\end{array}$ & $\begin{array}{l}0.237 \\
(0.168) \\
0.160\end{array}$ & $\begin{array}{l}-0.108 \\
(0.052) \\
0.038\end{array}$ & $\begin{array}{l}-\mathbf{- 0 . 2 5 0} \\
(0.054) \\
<0.001\end{array}$ & $*$ & & & \\
\hline
\end{tabular}

All metals were ln-transformed prior to analysis. 
Table 2. GLMM results (log-normal models), testing the effects of plant functional type, park age, their interaction and \% clay, bulk density

(Bulk Dens), \% soil moisture (\% Moist), $\mathrm{pH}, \%$ organic matter $(\% \mathrm{OM})$, concentration of that element in the soil ([] in soil) on various elements in the lysimeter leachate. Coefficients, standard errors (in brackets) and p-values are presented. Significant $p$-value $\leq 0.1$ are indicated in bold.

\begin{tabular}{|c|c|c|c|c|c|c|c|c|c|c|c|c|c|c|c|}
\hline & Int* & Decid & Lawn & Interm & Old & Clay & $\begin{array}{l}\text { Bulk } \\
\text { Dens }\end{array}$ & $\%$ Moist & $\mathrm{pH}$ & $\% \mathrm{OM}$ & [] in soil & $\mathrm{D} \times \mathrm{I}$ & Lx I & $\mathrm{D} \times \mathrm{O}$ & $\mathrm{L} \times \mathrm{O}$ \\
\hline Water Vol & $\begin{array}{l}8.915 \\
(0.355)\end{array}$ & $\begin{array}{l}-0.858 \\
(0.503)\end{array}$ & $\begin{array}{l}-0.812 \\
(0.426)\end{array}$ & $\begin{array}{l}-0.573 \\
(0.530)\end{array}$ & $\begin{array}{l}-0.703 \\
(0.492)\end{array}$ & & & $\begin{array}{l}0.434 \\
(0.183)\end{array}$ & & $\begin{array}{l}-0.415 \\
(0.190)\end{array}$ & & $\begin{array}{l}0.300 \\
(0.685) \\
0.662\end{array}$ & $\begin{array}{l}1.029 \\
(0.631)\end{array}$ & $\begin{array}{l}0.614 \\
(0.655)\end{array}$ & $\begin{array}{l}0.405 \\
(0.597)\end{array}$ \\
\hline $\mathrm{Cd}$ & $\begin{array}{l}-0.879 \\
(0.387) \\
0.023\end{array}$ & $\begin{array}{l}-0.955 \\
(0.577) \\
0.098\end{array}$ & $\begin{array}{l}-0.667 \\
(0.498) \\
0.181\end{array}$ & $\begin{array}{l}-1.120 \\
(0.574) \\
0.051\end{array}$ & $\begin{array}{l}-0.260 \\
(0.522) \\
0.619\end{array}$ & & & & & & & $\begin{array}{l}1.613 \\
(0.791) \\
0.041\end{array}$ & $\begin{array}{l}1.556 \\
(0.740) \\
0.035\end{array}$ & $\begin{array}{l}0.597 \\
(0.775) \\
0.441\end{array}$ & $\begin{array}{l}0.163 \\
(0.715) \\
0.820\end{array}$ \\
\hline $\mathrm{Cr}$ & $\begin{array}{l}2.093 \\
(0.369) \\
<0.001\end{array}$ & $\begin{array}{l}-0.668 \\
(0.562) \\
0.235\end{array}$ & $\begin{array}{l}-0.400 \\
(0.470) \\
0.395\end{array}$ & $\begin{array}{l}-1.002 \\
(0.553) \\
0.070\end{array}$ & $\begin{array}{l}-0.642 \\
(0.522) \\
0.219\end{array}$ & & & & & & & $\begin{array}{l}0.976 \\
(0.743) \\
0.189\end{array}$ & $\begin{array}{l}1.096 \\
(0.686) \\
0.110\end{array}$ & $\begin{array}{l}0.738 \\
(0.737) \\
0.316\end{array}$ & $\begin{array}{l}0.113 \\
(0.670) \\
0.866\end{array}$ \\
\hline $\mathrm{Cu}$ & $\begin{array}{l}4.781 \\
(0.370) \\
<0.001\end{array}$ & $\begin{array}{l}-0.674 \\
(0.548) \\
0.219\end{array}$ & $\begin{array}{l}-0.775 \\
(0.480) \\
0.106\end{array}$ & $\begin{array}{l}-0.973 \\
(0.558) \\
0.081\end{array}$ & $\begin{array}{l}-0.488 \\
(0.517) \\
0.345\end{array}$ & & & $\begin{array}{l}0.327 \\
(0.197) \\
0.096\end{array}$ & & $\begin{array}{l}-0.477 \\
(\mathbf{0 . 2 0 3}) \\
0.019\end{array}$ & & $\begin{array}{l}0.684 \\
(0.759) \\
0.368\end{array}$ & $\begin{array}{l}1.422 \\
(0.687) \\
0.038\end{array}$ & $\begin{array}{l}0.368 \\
(0.725) \\
0.611\end{array}$ & $\begin{array}{l}0.048 \\
(0.660) \\
0.943\end{array}$ \\
\hline $\mathrm{Fe}$ & $\begin{array}{l}7.459 \\
(0.373) \\
<0.001\end{array}$ & $\begin{array}{l}-0.616 \\
(0.539) \\
0.253\end{array}$ & $\begin{array}{l}-0.679 \\
(0.460) \\
0.140\end{array}$ & $\begin{array}{l}-1.143 \\
(0.550) \\
0.038\end{array}$ & $\begin{array}{l}-0.393 \\
(0.515) \\
0.446\end{array}$ & & & $\begin{array}{l}0.375 \\
(0.193) \\
0.052\end{array}$ & & $\begin{array}{l}-0.391 \\
(0.198) \\
0.048\end{array}$ & & $\begin{array}{l}0.306 \\
(0.733) \\
0.676\end{array}$ & $\begin{array}{l}1.132 \\
(0.660) \\
0.086\end{array}$ & $\begin{array}{l}0.134 \\
(0.704) \\
0.849\end{array}$ & $\begin{array}{l}-0.550 \\
(0.639) \\
0.390\end{array}$ \\
\hline $\mathrm{Mn}$ & $\begin{array}{l}3.085 \\
(0.439) \\
<0.001\end{array}$ & $\begin{array}{l}-0.037 \\
(0.664) \\
0.956\end{array}$ & $\begin{array}{l}-0.353 \\
(0.540) \\
0.513\end{array}$ & $\begin{array}{l}-0.555 \\
(0.638) \\
0.384\end{array}$ & $\begin{array}{l}0.751 \\
(0.589) \\
0.202\end{array}$ & $\begin{array}{l}-0.426 \\
(0.167) \\
0.011\end{array}$ & & $\begin{array}{l}0.465 \\
(0.238) \\
0.050\end{array}$ & $\begin{array}{l}-\mathbf{0 . 7 9 6} \\
\mathbf{( 0 . 1 7 9 )} \\
<\mathbf{0 . 0 0 1}\end{array}$ & $\begin{array}{l}-0.367 \\
(0.229) \\
0.110\end{array}$ & & $\begin{array}{l}0.279 \\
(0.848) \\
0.742\end{array}$ & $\begin{array}{l}0.563 \\
(0.758) \\
0.457\end{array}$ & $\begin{array}{l}-0.553 \\
(0.874) \\
0.527\end{array}$ & $\begin{array}{l}-1.370 \\
(0.741) \\
0.064\end{array}$ \\
\hline $\mathrm{Ni}$ & $\begin{array}{l}-0.456 \\
(0.543) \\
0.401\end{array}$ & $\begin{array}{l}-1.127 \\
(0.717) \\
0.116\end{array}$ & $\begin{array}{l}0.490 \\
(0.698) \\
0.483\end{array}$ & $\begin{array}{l}-0.530 \\
(0.775) \\
0.494\end{array}$ & $\begin{array}{l}0.033 \\
(0.754) \\
0.966\end{array}$ & & $\begin{array}{l}-\mathbf{0 . 5 6 0} \\
(0.205) \\
0.006\end{array}$ & $\begin{array}{l}-0.707 \\
(0.241) \\
0.003\end{array}$ & & & $\begin{array}{l}\text { 0.628 } \\
(0.220) \\
0.004\end{array}$ & $\begin{array}{l}1.811 \\
(1.028) \\
0.078\end{array}$ & $\begin{array}{l}0.784 \\
(0.974) \\
0.421\end{array}$ & $\begin{array}{l}1.277 \\
(1.010) \\
0.206\end{array}$ & $\begin{array}{l}-0.105 \\
(0.951) \\
0.912\end{array}$ \\
\hline $\mathrm{Pb}$ & $\begin{array}{l}0.732 \\
(0.440) \\
0.097\end{array}$ & $\begin{array}{l}-0.940 \\
(0.692) \\
0.174\end{array}$ & $\begin{array}{l}-0.613 \\
(0.585) \\
0.295\end{array}$ & $\begin{array}{l}-0.913 \\
(0.660) \\
0.167\end{array}$ & $\begin{array}{l}0.182 \\
(0.609) \\
0.765\end{array}$ & & & $\begin{array}{l}0.684 \\
(0.234) \\
0.003\end{array}$ & $\begin{array}{l}-0.372 \\
(0.183) \\
0.042\end{array}$ & $\begin{array}{l}-0.445 \\
(0.237) \\
0.061\end{array}$ & & $\begin{array}{l}0.736 \\
(0.895) \\
0.411\end{array}$ & $\begin{array}{l}0.474 \\
(0.811) \\
0.559\end{array}$ & $\begin{array}{l}0.514 \\
(0.913) \\
0.574\end{array}$ & $\begin{array}{l}-1.090 \\
(0.781) \\
0.163\end{array}$ \\
\hline $\mathrm{Zn}$ & 4.174 & -0.351 & -0.927 & -1.041 & 0.357 & -0.342 & & 0.370 & -0.638 & & & 0.717 & 1.295 & -0.439 & -0.247 \\
\hline
\end{tabular}




\begin{tabular}{|c|c|c|c|c|c|c|c|c|c|c|c|c|c|c|c|}
\hline \multirow{2}{*}{\multicolumn{2}{|c|}{$\begin{array}{r}(0.446) \\
<0.001\end{array}$}} & $(0.714)$ & $(0.587)$ & $(0.662)$ & $(0.614)$ & \multicolumn{2}{|l|}{$(0.173)$} & $(0.186)$ & \multicolumn{3}{|l|}{$(0.192)$} & \multirow{2}{*}{$\begin{array}{l}(0.929) \\
0.440\end{array}$} & $(0.836)$ & $(0.946)$ & (0.819) \\
\hline & & 0.623 & 0.115 & 0.116 & 0.561 & 0.048 & & 0.046 & $<0.001$ & & & & 0.121 & 0.642 & 0.763 \\
\hline \multirow[t]{2}{*}{$\mathrm{Al}$} & $\begin{array}{l}5.579 \\
(0.353)\end{array}$ & $\begin{array}{l}-0.717 \\
(0.461)\end{array}$ & $\begin{array}{l}-\mathbf{0 . 7 2 7} \\
(\mathbf{0 . 4 3 2})\end{array}$ & $\begin{array}{l}-0.447 \\
(0.533)\end{array}$ & $\begin{array}{l}-1.541 \\
(0.542)\end{array}$ & & & $\begin{array}{l}0.279 \\
(0.160)\end{array}$ & & & & $\begin{array}{l}1.375 \\
(0.677)\end{array}$ & $\begin{array}{l}-0.378 \\
(0.677)\end{array}$ & $\begin{array}{l}1.154 \\
(0.708)\end{array}$ & $\begin{array}{l}-1.090 \\
(0.756)\end{array}$ \\
\hline & $<0.001$ & 0.120 & 0.093 & 0.401 & 0.004 & & & 0.082 & & & & 0.042 & 0.577 & 0.103 & 0.149 \\
\hline \multirow[t]{2}{*}{ As } & $\begin{array}{l}1.369 \\
(0.394)\end{array}$ & $\begin{array}{l}-1.255 \\
(0.538)\end{array}$ & $\begin{array}{l}-1.131 \\
(0.503)\end{array}$ & $\begin{array}{l}-1.208 \\
(0.631)\end{array}$ & $\begin{array}{l}-1.019 \\
(0.638)\end{array}$ & & & & & & & $\begin{array}{l}2.318 \\
(0.755)\end{array}$ & $\begin{array}{l}0.988 \\
(0.780)\end{array}$ & $\begin{array}{l}1.077 \\
(0.829)\end{array}$ & $\begin{array}{l}-0.320 \\
(0.885)\end{array}$ \\
\hline & $<0.001$ & 0.020 & 0.024 & 0.055 & 0.111 & & & & & & & 0.002 & 0.205 & 0.194 & 0.717 \\
\hline \multirow[t]{2}{*}{$\mathrm{Be}$} & $\begin{array}{l}-0.876 \\
(0.402)\end{array}$ & $\begin{array}{l}-1.630 \\
(0.541)\end{array}$ & $\begin{array}{l}-1.031 \\
(0.522)\end{array}$ & $\begin{array}{l}-0.987 \\
(0.612)\end{array}$ & $\begin{array}{l}-1.662 \\
(0.620)\end{array}$ & & & $\begin{array}{l}0.306 \\
(0.186)\end{array}$ & & & & $\begin{array}{l}2.451 \\
(0.810)\end{array}$ & $\begin{array}{l}0.510 \\
(0.803)\end{array}$ & $\begin{array}{l}1.786 \\
(0.839)\end{array}$ & $\begin{array}{l}-0.037 \\
(0.916)\end{array}$ \\
\hline & 0.029 & 0.003 & 0.048 & 0.107 & 0.007 & & & 0.100 & & & & 0.002 & 0.525 & $\mathbf{0 . 0 3 3}$ & 0.968 \\
\hline \multirow[t]{2}{*}{ Co } & $\begin{array}{l}0.641 \\
(0.403)\end{array}$ & $\begin{array}{l}-1.015 \\
(0.589)\end{array}$ & $\begin{array}{l}-1.124 \\
(0.627)\end{array}$ & $\begin{array}{l}-1.192 \\
(0.620)\end{array}$ & $\begin{array}{l}-0.843 \\
(0.623)\end{array}$ & & & $\begin{array}{l}0.376 \\
(0.188)\end{array}$ & & & & $\begin{array}{l}1.841 \\
(0.940)\end{array}$ & $\begin{array}{l}0.375 \\
(0.902)\end{array}$ & $\begin{array}{l}0.396 \\
(0.938)\end{array}$ & $\begin{array}{l}-1.493 \\
(1.102)\end{array}$ \\
\hline & 0.111 & 0.085 & 0.073 & 0.054 & 0.176 & & & 0.046 & & & & 0.050 & 0.677 & 0.673 & 0.176 \\
\hline \multirow[t]{2}{*}{$\mathrm{Se}$} & $\begin{array}{l}4.240 \\
(0.387)\end{array}$ & $\begin{array}{l}-1.559 \\
(0.531)\end{array}$ & $\begin{array}{l}-0.929 \\
(0.497)\end{array}$ & $\begin{array}{l}-0.872 \\
(0.620)\end{array}$ & $\begin{array}{l}-1.475 \\
(0.628)\end{array}$ & & & & & & & $\begin{array}{l}2.482 \\
(0.746)\end{array}$ & $\begin{array}{l}0.754 \\
(0.771)\end{array}$ & $\begin{array}{l}1.678 \\
(0.818)\end{array}$ & $\begin{array}{l}0.150 \\
(0.876)\end{array}$ \\
\hline & $<0.001$ & 0.003 & 0.062 & 0.160 & 0.019 & & & & & & & $<0.001$ & 0.328 & 0.040 & 0.864 \\
\hline \multirow[t]{3}{*}{ V } & 2.630 & -1.551 & -1.693 & -1.160 & -1.173 & & & 0.621 & & -0.498 & & 2.202 & 0.895 & 1.317 & -0.528 \\
\hline & $(0.351)$ & $(\mathbf{0 . 4 5 3 )}$ & $(0.437)$ & $(0.576)$ & $(0.572)$ & & & $(0.212)$ & & $(0.252)$ & & $(\mathbf{0 . 6 8 3})$ & (0.671) & $(0.717)$ & $(0.757)$ \\
\hline & $<0.001$ & $<0.001$ & $<0.001$ & 0.044 & 0.040 & & & 0.003 & & 0.048 & & 0.001 & 0.182 & 0.066 & 0.486 \\
\hline \multirow[t]{2}{*}{ DOC } & $\begin{array}{l}5.071 \\
(0.529)\end{array}$ & $\begin{array}{l}-0.031 \\
(0.572)\end{array}$ & $\begin{array}{l}-0.742 \\
(0.434)\end{array}$ & $\begin{array}{l}-2.240 \\
(0.704)\end{array}$ & $\begin{array}{l}-1.216 \\
(0.596)\end{array}$ & & $\begin{array}{l}0.456 \\
(0.221)\end{array}$ & & & & $\begin{array}{l}0.861 \\
(0.308)\end{array}$ & $\begin{array}{l}1.213 \\
(0.852)\end{array}$ & $\begin{array}{l}2.364 \\
(0.797)\end{array}$ & $\begin{array}{l}-0.141 \\
(0.755)\end{array}$ & $\begin{array}{l}0.835 \\
(0.870)\end{array}$ \\
\hline & $<0.001$ & 0.957 & 0.087 & 0.001 & 0.041 & & 0.039 & & & & 0.005 & 0.154 & 0.003 & 0.852 & 0.338 \\
\hline \multirow[t]{2}{*}{ tot-N } & $\begin{array}{l}12.563 \\
(0.969)\end{array}$ & $\begin{array}{l}-1.299 \\
(2.042)\end{array}$ & $\begin{array}{l}-1.447 \\
(0.602)\end{array}$ & $\begin{array}{l}-8.989 \\
(1.579)\end{array}$ & $\begin{array}{l}-1.101 \\
(1.183)\end{array}$ & & $\begin{array}{l}0.764 \\
(0.266)\end{array}$ & $\begin{array}{l}-2.034 \\
(0.673)\end{array}$ & $\begin{array}{l}-1.519 \\
(0.297)\end{array}$ & $\begin{array}{l}1.979 \\
(0.879)\end{array}$ & & $\begin{array}{l}7.586 \\
(2.305)\end{array}$ & $\begin{array}{l}9.219 \\
(1.156)\end{array}$ & $\begin{array}{l}-1.027 \\
(2.115)\end{array}$ & $\begin{array}{l}1.623 \\
(0.923)\end{array}$ \\
\hline & $<0.001$ & 0.525 & 0.016 & $<0.001$ & 0.352 & & 0.004 & 0.003 & $<0.001$ & 0.024 & & 0.001 & $<0.001$ & 0.627 & 0.079 \\
\hline \multirow[t]{2}{*}{$\mathrm{NO}_{3} \mathrm{~N}$} & 6.763 & 0.093 & 3.513 & -4.292 & 5.302 & & & -3.861 & & & 3.686 & 5.189 & 6.733 & -3.247 & -5.537 \\
\hline & $\begin{array}{l}(1.802) \\
<0.001\end{array}$ & $\begin{array}{l}(3.998) \\
0.981\end{array}$ & $\begin{array}{l}(1.829) \\
0.055\end{array}$ & $\begin{array}{l}(3.133) \\
0.171\end{array}$ & $\begin{array}{l}\text { (2.399) } \\
0.027\end{array}$ & & & $\begin{array}{l}(1.122) \\
<\mathbf{0 . 0 0 1}\end{array}$ & & & $\begin{array}{l}(1.530) \\
0.016\end{array}$ & $\begin{array}{l}(4.870) \\
0.287\end{array}$ & $\begin{array}{l}\text { (2.771) } \\
0.015\end{array}$ & $\begin{array}{l}(4.240) \\
0.444\end{array}$ & $\begin{array}{l}\text { (2.310) } \\
0.017\end{array}$ \\
\hline tot-P & 7.313 & -1.314 & -1.288 & -1.232 & -0.459 & & & 0.377 & & -0.539 & & 1.117 & 1.969 & 1.218 & 0.580 \\
\hline
\end{tabular}




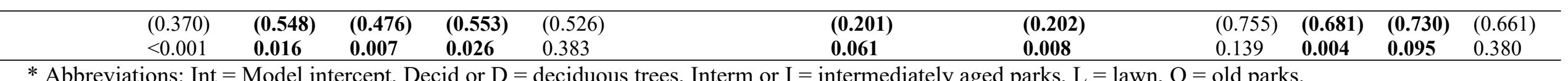

* Abbreviations: Int = Model intercept, Decid or D = deciduous trees, Interm or I = intermediately aged parks, $\mathrm{L}=$ lawn, $\mathrm{O}=$ old parks. 
